\title{
Propertius, patronage and politics
}

It has become a commonplace of Latin literary criticism that we should avoid thinking of authors as 'Augustan' or 'anti-Augustan'. ${ }^{1}$ This paper will ignore such admonitions. I accept many of the judgements that go along with them: the meaning of the terms shifts according to context, and over time; there is an inevitable tendency for modern interests and the views of individual critics to colour the debate, and in some cases to determine the conclusion. Above all, our interpretations will simplify complexities and thus miss truths. However, it seems reasonable to observe that such points may be made about any attempt to read the past. As a historian of literature my task, I believe, is to tell the story as accurately, perceptively and interestingly as I can.

The poets of the Augustan period treat political figures and issues in their poetry. It is desirable that critics try to explain why this is; part of that explanation will come from attempts to work out the meaning of individual passages, and through those the purposes of the poet. 'Meaning' here is not a conglomeration of the interpretations proffered over centuries, important though the history of reception is to our reading of texts, but rather the sense, or senses, intended by the writer. No essay at determining this will be entirely successful, of course, nor could we know if one were; but while we remain interested in the past that is no reason for eschewing the search. ${ }^{2}$

${ }^{1}$ See especially D.F.Kennedy, "'Augustan" and "anti-Augustan": reflections on terms of reference', in A.Powell (ed.), Roman poetry \& propaganda in the age of Augustus (London, 1992), 26-58; also D.C.Feeney on pp. 1-5 of the same volume; K.Galinsky, Augustan culture (Princeton, 1996), e.g. 5, 228.. Similar views are espoused by M.R.Gale, 'Propertius 2, 7: militia amoris and the ironies of elegy', JRS 87 (1997), 77-91, discussed below. Responses rather like mine have come from A.R.Sharrock, 'Ovid and the politics of reading', MD 33 (1994), 97-122 (again touched on below); Sergio Casali, 'The art of making onself hated: rethinking (anti-)Augustanism in Ovid's Ars Amatoria', in R.Gibson et alii (edd.), The Art of Love: Bimillennial Essays on Ovid's Ars Amatoria and Remedia Amoris (Oxford, 2006), 216-34; and P.J.Davis, Ovid \& Augustus: a political reading of Ovid's erotic poems (London, 2006), 9-22 (some later sections in this generally subtle book use Propertius as a simple foil for Ovid [e.g. 52-62 on Arethusa and Laodamia: discussed in the review by F.Nau, BMCR 2007.06.43], and so might give the unfortunate implication that his is a comparatively unpolitical text).

The following are also referred to by author's name in what follows: B.K.Gold, Literary patronage in Greece and Rome (Chapel Hill, 1987), Chapter 6 'Propertius', 142-72; H.P.Stahl, Propertius: 'Love' and 'War' - Individual and State under Augustus (Berkeley 1985); P.A.Miller, Subjecting verses: Latin Love Elegy and the emergence of the Real (Princeton, 2004).

${ }^{2}$ Cf. E.D.Hirsch, Validity in interpretation (Yale, 1967), 173: 'Correctness is precisely the goal of interpretation and may in fact be achieved, even though it can never be known to be achieved.' I am grateful to the anonymous referee for drawing my attention to the relevance of Hirsch's book, which argues for an intentionalist position with much good sense and sharp observation (though at times with excessive confidence). A few further examples, shorn of their contexts: 'the interpreter ... preserves his own standpoint and, at the same time, imaginatively realizes the standpoint of the speaker. This is a characteristic of all verbal intercourse' (135, n.4); 'all serious students of texts from the past ... are historians' (138); ‘to dream that all expert interpretations are ultimately members of one happy family is to abandon critical thinking altogether' (167). An emphatically pluralist revision of some of 
After laying a careful theoretical groundwork, Kennedy's paper on 'Augustan' and 'antiAugustan' (n.1) explores ambiguities in the ideological positioning of texts by Livy and Ovid that deal with the Romulus and Numa myths. He writes (pp. 43, 46):

These questions are part of the traditional problematic which attempts to ground its answer exclusively in the individual, Livy. ...

Ovid may well have thought he was supporting or criticising Augustus in his various works, but control of meaning is always only partial .... Readings of Ovid (then and now) as 'oppositional' or 'subversive' may have had the unforeseen consequence for those involved of consolidating the position of Augustus.

I do not doubt that there is much to be gained from realising the indirect support for the structures of society offered by texts that on the surface are seeking to change or challenge those structures, or that it is reasonable to investigate texts as creations of their culture at large. What puzzles me is that in asserting such a position, Kennedy seems to deny that there is any point in inquiring into the intention of the individuals Livy or Ovid. ${ }^{3}$ Though Ovid could not control the reception of his texts, it does not follow that he wrote with no intention. Modern modes of reading enable us to go beyond noting the way that Ovidian responses to Augustan panegyric are couched in the terms that others use sincerely, by finding reinforcement of the regime's power in the adoption of language it approves. But this is an inevitable part of engagement with power, and it tells us nothing about the poet's meaning. Unless we consider the attitudes of individuals, we simply cannot get at political tone. Nor do I see how a modern reading of Ovid as opposing Augustus consolidates the 'position' of the princeps; it certainly cannot affect the historical individual, who is long dead, even as diuus. ${ }^{4}$ It may reinforce the dominance of the figure in discourses about poetry of the period, but it can also undermine his position as the 'ideal' emperor, if readers are forced to consider his violence, intolerance, malice and abuse of power.

Though our findings in a text are undoubtedly conditioned by our expectations and presuppositions it does not do justice to the seriousness of academic endeavour if we stress the inevitability of our predecessors finding evidence to support their theses. Though this may be true of an individual, what matters is the quality of the evidence and the argument, the extent to which the interpretation is grounded in evidence and thus persuasive. Moreover, it is not necessarily the case that the critic finds the text mirroring his or her attitudes: Stahl's Vergil is markedly pro-Augustan, unlike his Propertius. ${ }^{5}$ The reason why we bring presuppositions to the text is because of our knowledge of human behaviour, and of other texts, especially other parts of the corpus.

What matters is that we are aware of the different questions we bring to our texts, and how different answers will result. The poet may mean one thing; the text, if read with a mind that is avoiding intentionalism, may be interpreted as meaning something very different. In what follows I am mainly concerned with a single poet's 'intention'; I am of course aware that I cannot express my interpretation in terms that Propertius could understand, but prefer the haze of modern English academic discourse to silence. In trying to reconstruct his meaning

Hirsch's positions can be found in the second and third chapters of Malcolm Heath's Interpreting Classical Texts (London, 2002).

${ }^{3}$ Cf. Heath (n.2), 93-4: 'Would it not be arbitrary to exclude an interest in individual human beings from the scope of human curiosity?'

${ }^{4}$ That said, I do try to remember to date letters written in the eighth month to Sextile.

${ }^{5}$ Similarly Davis, Ovid \& Augustus, 132. 
in various poems, I assume that (though corrupted in transmission) they were originally written by a single individual, whose character and attitudes had similar incoherence and similar unity to those we experience around us, whether through personal acquaintance or other media. In his poetry he expresses a face to the world, and identifies it with the name Propertius. This provides a continuity that should radically affect our reading. The attitudes of the persona are established early on; this enables the poet to be less overt later, yet expect all he writes to be read as coming from the elegiac lover.

\section{Tullus in Books 1 and 3}

Propertius closes his first book with two short poems, the first (1.21) a quasi-sepulchral epigram addressed to a fellow soldier by Gallus, an opponent of Octavian who has broken out from the siege of Perusia but subsequently been killed, the second (1.22) a sphragis poem in which the poet answers questions about his origin and identity. Though these poems pick up some themes from earlier parts of the book, ${ }^{6}$ they also draw attention to themselves by their difference from the erotic material that dominates the book. The reader is forced to ask what they are doing in this collection. In their brevity ${ }^{7}$ and their generic resonances, ${ }^{8}$ they recall Hellenistic epigram, and there may be a literary point to this: ${ }^{9}$ the poet closes his book with poems that revisit the form of one of his main models, but does so while avoiding the erotic material that he has transmuted into more substantial elegies. More pertinently, for this discussion, they demand thought about the poet's biography away from his love affair with Cynthia. The final poem of the book presents us with Tullus, who (amongst other roles) functions as a model reader, asking questions about the poet's family background and home. But the answer given is a very partial one, and defines Propertius's origin with emphatic reference to the killing fields of the Perusine War. Though the family of his supposed patron may be supporters of Caesar, perhaps even reconciled after previous opposition, yet Propertius, twelve years or so after the event, still sees the siege of Perusia as a defining moment in his life.

Readers have in recent decades been offered two opposed approaches. With du Quesnay they can note that the Tullus addressed in 1.22 (to whom the book as a whole is dedicated with the address in 1.1) was the nephew of a man given positions of power by Caesar, and suppose that the poet uses the statement of allegiance to this patron as a way of defusing any negative implications that might be found in his reference to the Perusine War. Alternatively, with

\footnotetext{
${ }^{6}$ G.O.Hutchinson, JRS 74 (1984), 103-6.

${ }^{7}$ Ten lines each; 1.12 at 20 lines is the shortest poem earlier in the book.

${ }^{8}$ See e.g. DuQuesnay (n.15) on the links with sepulchral epigram in 1.21; 1.22 has often been identified as a sphragis (see e.g. G. Williams, Tradition and originality in Roman poetry (Oxford, 1968), 177; E.Schulz-Vanheyden, Properz und das griechishe Epigramm, (diss. Münster, 1969), 18-28).

${ }^{9}$ A similar argument can be used as partial explanation of 1.20 , the other exceptional poem in the book (in that it is the longest, and the first to be concerned with homosexual love-not a word of Cynthia): as a narrative of the Hylas story, introduced by a personal frame, it mimics the form and the content of a Theocritean idyll, which the poet may regard as an important model for the mix of personal and mythological in his poems, but with the major difference that the elegist regularly expands the personal frame and contracts the mythological tale to make something quite new.
} 
Stahl, we can give greater weight to the apparent identification of his family as one that opposed Caesar in that war, and suffered.

To suppose the poet's identification with his patron is greater than that with his own family is difficult when the loss of a relative is so emphasised $(1.22 .6-8)^{10}$ :

sed mihi praecipue, puluis Etrusca, dolor:

tu proiecta mei perpessa es membra propinqui,

tu nullo miseri contegis ossa solo.

It would require a vivid picture of a close relationship, perhaps reinforced by open

acknowledgement of the change of allegiance, such as we get in Horace, who fought for

Brutus at the Battle of Philippi, but has become a Caesarian by the time of Actium (e.g. epod.

1, 9; carm. 1.37; epist. 2.2). In fact there is nothing to suggest closeness between Tullus and Propertius. In 1.1 Tullus is nothing more than a name; in 1.6 and 1.14 he is used to contrast with the poet—a soldier and an administrator for the empire set against the stay-at-home lover; a man of wealth who lacks the real wealth that love brings Propertius. There is no warmth here (contrast Odes 1.21, and indeed some other friends addressed by Propertius in book 1, especially Gallus), no jocularity (contrast Epode 3), no sense of obligation to do what the patron expects (contrast Tibullus, who has accompanied Messalla on campaign [1.3.1-2, 1.7.9] and produces poems that celebrate his birthday [1.7] and his son's appointment to the quindecimvirate [2.5]). The strongest evidence that Tullus is a poetic tool, used to exploit the poetic potential of patronage, rather than a reflection of a real-life relationship, comes when he returns towards the end of book 3. There is an obvious poetic point to the re-appearance here: the Cynthia cycle is drawing to a close, and Propertius revisits and reverses a number of motifs from book 1. In 3.21 he embarks on the journey abroad that he has been unable to pursue in 1.6 (or Cynthia in 1.8); in 3.22 he summons back to Italy the Tullus who has been sent abroad in 1.6, so that he can serve his country at home, by getting married; but nothing is said about a current life dispensing justice and waging war-the ambitious young man of 1.6 has, it seems, spent his time enjoying the tourist spots of Asia: a surprisingly satirical revelation about a patron, and this, it must be emphasised, without any counterbalancing positive images. Part of the function of a poem like 3.22 is to inform the reading of the earlier poems it recalls. My conclusion is that Tullus is intended to be read not as a real patron in either book, but as a poetic imitation of one. ${ }^{11}$

One might go beyond this and wonder whether the signs of antipathy are perhaps real. Catullus in poem 11 allows a satirical edge into his request that Furius and Aurelius take a message of divorce to his puella by describing at length the distant places they would willingly visit along with him; in 1.6 Propertius caps these exotic destinations by expressing his willingness to accompany Tullus to the mountains of the legendary north, or the regions beyond Memnon's home in the mythical south; and then undermines his commitment by showing it as lesser than uerba puellae (5). He imagines Tullus going beyond his uncle's

\footnotetext{
${ }^{10}$ Passages of Propertius are cited in the form in which they appear in the new Oxford Classical Text; variants and conjectures are not generally noted except in cases where they are important for the discussion.

${ }^{11}$ J.Griffin, Latin poets and Roman life (London, 1985), 56-7 makes similar observations in arguing that Tullus is an equal, a friend, rather than a patron: not everything said to him needs to be straightforwardly complimentary. Even closer to my view is J.E.G.Zetzel, 'The poetics of patronage in the late first century B.C.', in Literary and artistic patronage in ancient Rome (ed. B.K.Gold; Austin, Texas, 1982), 87-102, at 99, who sees 3.22 as an ironic completion of 1.6, with the reader as the real addressee, not Tullus.
} 
achievements as a magistrate, as if it were etymologically feasible to go on ahead of the praetor (19). ${ }^{12}$ The grand claims earlier in the poem are overturned by the emphasis on eastern wealth and luxury in 31-2; at best Tullus will be accepti pars ... imperii (34). The disdain in 1.14 is rather greater: no active ruler of empire now, Tullus lies luxuriously by the Tiber, so little engaged that he can be distracted by observing the different speeds of the passing traffic on the river (3-4). Everything involved in Tullus's life of luxury is overwhelmed by the joys, and the pain, of love. The final couplet sums up the Propertian scale of values:

quae mihi dum placata aderit, non Lyda ${ }^{13}$ uerebor regna uel Alcinoi munera despicere.

uerebor disdainfully echoes the uereor in 1.6.1 (Non ego nunc Hadriae uereor mare noscere tecum), which has been quickly exposed as insincere. Whatever pride Tullus may have in his position, he does not begin to match the wealth or power of Croesus, the gardens or generosity of Alcinous.

\section{Propertius 1.21 and 1.22}

Against this background, let us look in more detail at 1.21-2. The sphragis poem begins with Tullus asking questions:

Qualis et unde genus, qui sint mihi, Tulle, penates, quaeris pro nostra semper amicitia.

si Perusina tibi patriae sunt nota sepulchra, Italiae duris funera temporibus,

cum Romana suos egit discordia ciuis, (sed mihi praecipue, puluis Etrusca, dolor:

tu proiecta mei perpessa es membra propinqui, tu nullo miseri contegis ossa solo):

proxima suppositos contingens Vmbria campos me genuit terris fertilis uberibus.

Reference to length of friendship occurs elsewhere in similar expressions: in particular Cic. fam. 13.77.3 praeterea a te peto ... pro nostra amicitia et pro tuo perpetuo in me studio ut ... and Propertius 1.20.1, where the phrasing Hoc pro continuo te, Galle, monemus amore seems designed for ambiguity: the advice rewards Gallus's friendship with Propertius, but it is also intended to prolong Gallus's liaison with Hylas. However, reference to continuation or perpetuity is not an inevitable constituent ${ }^{14}$, and it is strange here, where the questions Tullus is imagined as posing imply that he is scarcely more than an acquaintance, not a life-long friend. So, if semper goes with amicitia, it seems to be a sarcastic repetition of Tullus's claim to undying friendship. If it goes with quaeris, it implies a nagging persistence. In either case, it contributes to the sequence of syllables that helps to answer the question, in this book

\footnotetext{
${ }^{12}$ The background to the etymological play is well explored by F.Cairns, AJPh 95 (1974), 160-3, though he comes to different conclusions about the effect.

${ }^{13}$ Lyda Markland: ulla w.

${ }^{14}$ For pro amore or pro amicitia, but without reference to continuation or perpetuity see Cic. Phil. 1.12, 10.6; Att. 3.18.1; fam. 6.13.1, 8.2.1 [Caelius], 11.28.1, 13.50.2; Sall. Iug. 9.2; Tac. ann. 4.40; Plin. ep. 1.5.17.
} 
that does not otherwise include the poet's name: PRO nostra semPER amiciTIa ${ }^{15}$.

On the basis of verse 3 Syme repeatedly claimed that the Volcacii Tulli came from Perusia. ${ }^{16}$ But Propertius indicates in this poem that Tullus needs to be told about his family and origin. This implies a distance between them. Even if the Volcacii come from Etruria (as the root of the name and its presence on Etruscan inscriptions suggest), they are not from Perusia therefore. Du Quesnay builds on Syme's claim, to argue that Volcacius Tullus was a supporter of Lucius Antonius during the siege, but reconciled to Octavian by the time they became consuls together in 33. However, there are other stories that would account for the appearance of the name Volcacius in Perusine inscriptions (CIL 1.2772; 11.2083-4): it is possible for example that the family was rewarded for support of Octavian with a gift of land in the area. Propertius's addresses of Tullus would then have a consistently sarcastic edge.

Du Quesnay's long paper on $1.21^{17}$ gathers together much useful information, both historical and literary. However, many of the conclusions he reaches seem to me mistaken, in general interpretation because he sees the patronage of the family of Tullus as the key to understanding Propertius' attitude towards political matters. As we have seen, there is not adequate evidence to show that the patronage of Tullus was important to Propertius: he explicitly rejects the opportunity to accompany him as part of his uncle's cohors in 1.6, and in the other poems in which he features the relationship is one of distance and contrast, not intimacy and respect. At a more basic level, Du Quesnay sees that the parallels he adduces from the opening lines of Latin (and Greek) epitaphs ${ }^{18}$ strongly imply that the addressee is a typical member of a class, not a specific individual; but he fails to give due weight to the point.

$\mathrm{Tu}$, qui consortem properas euadere casum, miles ab Etruscis saucius aggeribus, quid nostro gemitu turgentia lumina torques? pars ego sum uestrae proxima militiae.

sic te seruato possint gaudere parentes: me soror Acca tuis sentiat e lacrimis

Gallum per medios ereptum Caesaris enses effugere ignotas non potuisse manus;

et, quaecumque super dispersa inuenerit ossa montibus Etruscis, haec sciat esse mea.

In the phrase miles ab Etruscis saucius aggeribus, Propertius makes the class smaller than the usual uiator or hospes, because the particular circumstances of the speaker require a quick response to the request made: the body will need finding quickly if it is to be buried properly; and during, or immediately after, the siege of Perusia the only travellers likely to be willing and able to bring the news to the dead man's family are fellow soldiers who have escaped, honourably wounded.

I take verse 4, pars ego sum uestrae proxima militiae, to mean 'I am one of your fellow

\footnotetext{
${ }^{15} \mathrm{I}$ am ashamed to say that I cannot recover the identity of the text or individual that first drew this play to my attention.

${ }^{16}$ The Roman Revolution (Oxford, 1939), 466; JRS 39 (1949), 18; Roman papers 2.544, 603 etc.

${ }^{17}$ I.M.LeM.DuQuesnay, 'In memoriam Galli: Propertius 1.21', in A.J.Woodman \& J.Powell (edd.), Author and audience in Latin literature (Cambridge, 1992), 52-83 (and 225-36).

${ }^{18}$ e.g. CE 119, 513, 848, 1055, 1056, 1451, 1537, 1591.
} 
soldiers, and the closest one to you now': it says nothing about their previous acquaintance beyond the fact of being in the same force. This lack of further connexion between the two is also implied by the failure of the poem to request burial from the addressee. Poem 1.22 tells us of a relative of Propertius killed in the Perusine War and never buried. There is a very strong implication that this poem serves to link the previous epigram to the author, and the reader is thus invited to understand that the speaker of 1.21 and the propinquus of 1.22 .7 are one and the same. In that case the scene evoked in 1.21 is imaginary. Despite breaking out through Caesar's lines, Propertius's relative never arrived home, and his body was never discovered. ${ }^{19}$ Though the family might have wished at the worst for the kind of message requested in verses 7-10, it never came. And, it seems, the young Propertius wrote this sepulchral epigram to express their longing to find the body so that they could bury it. If this biographical speculation is not true, it is at least the picture the poet wished to create in the minds of his readers.

There is topos 'saved from $\mathrm{x}$, only to be killed by $\mathrm{y}^{\prime}$, which we find in a few epigrams in the Anthologia Palatina. Fedeli and du Quesnay see a similar point here, and make something of the assumption that the ignotae manus were bandits, not Caesar's soldiers: du Quesnay goes as far as to claim 'Augustus can bear no responsibility for Gallus' death'. But the text does not offer the elemental antithesis of A.P. 7.289 and 550 ('shipwrecked, but killed on land by a wolf') or 640 ('saved from storm, killed in a calm by pirates'), and there is a reason for the vagueness: the family could hardly know who the killers were if they did not know the whereabouts of the body. The implied reality has a message coming home that Gallus had been seen to escape during a sortie, but no Gallus following; the natural assumption was his death at hands unknown. ${ }^{20}$

We have here two poems which bring out a remarkable element in the poet's identity: he is a lover, but in addition he is a man who lost a relative in the Perusine War. There can be little doubt that this was a very bloody episode. Some believed the victor had behaved with the utmost barbarity, 300 senators and knights killed as sacrificial victims on the altar of the Divine Julius (Suet. Aug. 14.1):

Perusia capta in plurimos animaduertit, orare ueniam uel excusare se conantibus una uoce occurrens 'moriendum esse'. scribunt quidam trecentos ex dediticiis electos utriusque ordinis ad aram Diuo Iulio extructam Idibus Martiis hostiarum more mactatos. If we ask who will have told such stories, who are most likely to have believed them, there is an obvious answer: opponents, and those who lost loved ones in mysterious circumstances. Propertius focuses on an unburied corpse, and a personal loss, but the phrasing of 1.22 has vivid evocations of slaughter: Perusina ... patriae ... sepulchra, Italiae duris funera temporibus. The discord comes from Rome (Romana ... discordia, 5), but the devastated citizens, her citizens now, are locals. Umbria has truly become a 'land of shades', the earth fertilised by the blood of the dead. ${ }^{21}$ These sentiments come with an acknowledgement, but

\footnotetext{
${ }^{19}$ Similarly D.A.Traill, AJPh 115 (1994), 89-96, at 94: 'The only facts of which we can be reasonably certain are that Gallus fought at Perusia, that he managed to break out through the siege works, that he subsequently disappeared, and that his body was never found.'

${ }^{20}$ Conceivably bandits, but no less possibly a Caesarian contingent operating behind the front lines (so H.N.Parker, CPh 86 (1991), 330): one might think of Nisus and Euryalus in Aeneid 9.

${ }^{21}$ Two puns in 9-10 are brought out by M.Hendry (CQ 47 (1997), 602-3): Umbria = 'land of shades'; contingens = 'polluting'; he builds on the note of H.N.Parker, Mnemosyne 45 (1992), 88-92, which argues that Umbria has been fertilised by the blood and bones of many corpses.
} 
(if I am honest) without any great emphasis, that the family has been opposed to the young Caesar; but unlike Horace's reminiscences of his republican youth, when he fought on the wrong side at Philippi (Carm. 2.7.9-14, Ep. 2.2.46-8; and cf. Carm. 3.14.28), they are not matched by announcements of change of allegiance. When Propertius goes out of his way to present himself as an Umbrian patriot, ${ }^{22}$ scarred by the memory of the War and the loss of the propinquus, we cannot think of it as a light thing, easily discarded. Like his total immersion in his love for Cynthia, and rejection of all that threatens it, this is a fundamental statement of identity. My reading here, as regards the politics of these poems, is thus essentially in agreement with Stahl's.

In her paper , 'Ovid and the politics of reading', Sharrock discusses the Ars amatoria (and the Georgics) and persuasively argues that the political importance of sexual relations (as of the farmer) in the Augustan age necessarily involves the reader of the didactic in a judgement on political meaning:

the Ars Amatoria poses as teaching adultery. The point is that by posing as learning how to commit adultery (and get away with it!) readers are performing a political act. It was no doubt possible to make reading the Ars a political act of a very different nature: a reading that says 'this is bad behaviour' or 'what a good thing we have Augustus to sort this sort of thing out'. What would be difficult, it seems to me, would be to remove the political dimension altogether. ${ }^{23}$

In the case of Propertius, it is not so much genre that requires this, but the persona presented by the poet. Having expressed his identity in the way he does in 1.21 and 1.22, he forces readers to ask of all later political statements, 'Has he come round to the Caesarian party, or does he retain the familial antagonism that was so important to him in closing book 1?'

Propertius and Maecenas: 2.1 and 3.9

Book 2 begins with familiar material (2.1.1-8):

Quaeritis unde mihi totiens scribantur amores, unde meus ueniat mollis in ora liber.

non haec Calliope, non haec mihi cantat Apollo: ingenium nobis ipsa puella facit.

siue illam Cois fulgentem incedere cerno, 5 totum de Coa ueste uolumen erit;

seu uidi ad frontem sparsos errare capillos, gaudet laudatis ire superba comis; ...

Though the opening words recall the Qualis et unde .../ quaeris of 1.22.2) ${ }^{24}$, the poet continues to write amores; his book is again mollis (i.e. 'elegiac'). He both acknowledges and denies the importance of Callimachus as a model (3-4). However Cynthia dresses, whatever

22 There is some discussion along these lines in M.Sordi et alii, 'L'integrazione dell' Italia nello stato romano’, Contributi dell’ Istituto di storia antica 1 (1972), 146-75, especially 1659.

${ }^{23}$ A.R.Sharrock, MD 33 (1994), 107-8.

${ }^{24}$ As Sergio Casali reminds me, adding that the Augustan Apollo is one possible subject in non haec mihi cantat Apollo (2.1.3: the poet sings amores, not political themes), and noting that the unde mihi of 2.1.1 is itself echoed in a political context at 2.7.13. 
she does, he will produce a book, no, a genre, in response (5-16). But in 17 we have a shock, an address to the Über-patron of Roman culture:

quod mihi si tantum, Maecenas, fata dedissent,

ut possem heroas ducere in arma manus,

non ego Titanas canerem, non Ossan Olympo

impositam ut caeli Pelion esset iter.

nec ueteres Thebas, ...

bellaque resque tui memorarem Caesaris, et tu

Caesare sub magno cura secunda fores.

Here is just the kind of passage we have to read against the background of book 1, and poems 21-2 in particular. ${ }^{25}$ There we found the bitter memory of a death in the family suffered when fighting a particularly bloody conflict against the young Octavian. Now we read an address to Caesar's right-hand man. Is this a major shift in allegiance, such as Horace underwent, the tribunus militum under Brutus at Philippi turned into the hanger-on who accompanies Maecenas to Brundisium (serm. 1.5) and Actium (epod. 1, 9)? Or is the effect of the earlier poems to make us look sceptically at the relationship depicted here, a parody of the poetry written for Maecenas by his famous parasites composed by one whose sharing of Etruscan origin only emphasises his distance from his addressee?

The regular response to the existence of this poem and 3.9 in the Propertian corpus is to identify Maecenas as the poet's patron, and then to use that fact as a basis for interpretation. Maecenas we know was the patron of Vergil and Horace and others; if another poet addresses him that means he was also that poet's patron: that's how the argument seems to run. ${ }^{26}$ If there is anything I hope to achieve through this paper, it is to encourage others to question that assumption. In the case of both Vergil and Horace we have evidence from the ancient lives that the relationship with Maecenas was engaged and serious: he reads out sections of the Georgics when Vergil's voice give out (we are told) ${ }^{27}$; he uses his will to demonstrate his

${ }^{25}$ Cf. Miller 144: ' $\ldots$ the reference to the cruelties of the Perusine War in which Propertius had lost a kinsman, as he tells us in 1.22. It would be surprising indeed if at the beginning of the next book all this had been forgotten and Propertius had been converted into a subtle but unrepentant apologist for the Augustan regime.'

${ }^{26}$ Of course there are scholars who have been more cautious, such as Gold, or more critical, most notably Stahl. But the following expressions are not untypical: 'by the time Book 2 was published in collected form Propertius had already entered the circle of Maecenas' (F.Cairns, GB 8 (1979), 186, with a justifying note reading 'The book is dedicated to Maecenas by the address to him at Prop. 2.1.17'; 'Maecenas ist inzwischen auf den Dichter aufmerksam geworden und hat ihn für Augustus gewonnen. ... Maecenas, ... Förderer von Horaz, Vergil und Properz.' (G.Luck, Artemis edition (Düsseldorf, 1996), 391); 'Propertius has followed Virgil and Horace into Maecenas' circle of patronage' (L.Morgan, in O.Taplin (ed.), Literature in the Greek and Roman worlds (Oxford, 2000), 381); 'three-quarters of his verse was written while he was the recipient of quasi-official imperial patronage from Augustus' informal "Minister of Culture"' (M.Janan, The politics of desire (Berkeley, 2001), 12); 'it is no accident that ... the figures of Maecenas and Augustus loom large over it. Propertius has begun to move in the imperial circle.' (Miller 130). Even the sensitive examination of these issues by H.Tränkle, 'Properzio poeta dell' opposizione politica?', Colloquium Propertianum 3 (Assisi 1983), 149-62, is undermined by belief in 'il suo benefattore Mecenate'; he is also able to understate the importance of 1.21-2 because he starts in the middle.

${ }^{27}$ Vita Donati 27. 
closeness to Horace $^{28}$. It is true that Vergil mentions Maecenas only in the Georgics, and in a slightly limited way even there, but didactic and epic leave him less opportunity than a more personal poet might have for effusive demonstration of his affection; and there is the exquisite patterning of the addresses (1.2, 2.41, 3.41, 4.2), and a thoroughness to the commitment. As he presents it, in writing the third book of the Georgics, he does carry out the haud mollia iussa of his patron, the man without whom he cannot achieve anything lofty (Verg. geo. 3.40-2):

interea Dryadum siluas saltusque sequamur

intactos, tua, Maecenas, haud mollia iussa:

te sine nil altum mens incohat.

Moreover, we have warrant for trusting the impression given by the Vitae in the Satires of Horace, which identify Vergil as one of those who actually introduced the rising southerner to the great man (serm. 1.6.55), and include him amongst those enjoying life in the circle of Maecenas (serm. 1.5.40, 48; 1.10.81). The prominent address to Vergil in Odes 1.3 contributes to this sense of togetherness. ${ }^{29}$ Horace's poetry addressed to or concerned with Maecenas gives us a picture of a lively, complex and affectionate friendship, in which the personal remembrance of honours paid by the public (Odes 1.21) is set beside teasing (Odes $2.12,17)$ and thoughtful examination of their model roles as patronus and cliens for the education of readers (serm. 1.9, epist. 1.7). Though some of the Epodes $(4,7,16)$ follow the Catullian line, by using politics as material for polemic and invective, not for praise, encomium is the manner of those political epodes that are marked as written after Horace has been brought into the circle of Maecenas $(1,9) .{ }^{30}$ Maecenas is there in the first line (serm. 1.1.1), and he is celebrated, usually in first and penultimate position (cf. epist. 1.1.1 Prima dicte mihi, summa dicende Camena), in all books bar epistles 2 (which seeks out other dedicatees for its three poems).

By contrast Propertius gives Maecenas just two poems: 2.1, admittedly in the place of honour in this collection, and 3.9, neither first nor last nor at the mid-point. In 2.1 he says that he would write poetry that celebrates Caesar and Maecenas if he could write epic, but he is a love poet, so he must write about love in elegiac couplets, and cannot produce an epic. We do not know what reality lies behind this composition (an invitation to write an epic? an invitation to join the team and write Augustan panegyric? an invitation to dinner? nothing?), but the poem remains a refusal: he is not going to do what he presents Maecenas as wanting from him (contrast Vergil in Georgics 3.40-2, cited above). It seems to me bizarre to base an unquestioning belief in Propertius's acceptance of Maecenas's patronage on such a foundation.

Poem 3.9 repeats the refusal; but caps it, by explaining that it is Maecenas's own mode of life that the poet follows (21-2):

at tua, Maecenas, uitae praecepta recepi, cogor et exemplis te superare tuis.

\footnotetext{
${ }^{28}$ Suet. de poetis fr. 40: 'Maecenas quantopere eum dilexerit satis testatur illo epigrammate: ni te uisceribus meis, Horati,/ plus iam diligo, tu tuum sodalem/ Ninnio uideas strigosiorem; sed multo magis extremis iudiciis tali ad Augustum elogio: Horati Flacci ut mei esto memor.' ${ }^{29}$ R.Thomas, Virgil and the Augustan reception (Cambridge, 2001), 55-65, casts doubt on the closeness of the relationship between Horace and Vergil; but can hardly challenge the notion that Horace lays claim to friendship early in his career.

${ }^{30}$ On the chronology see e.g. R. G. M. Nisbet, 'Horace: life and chronology', in S. J. Harrison (ed.), The Cambridge Companion to Horace (Cambridge, 2007), 7-21.
} 
'But I have received your rules for life, Maecenas, and I am forced to overcome you by following your example.' Just as the great man remains a knight, refusing public office and the prospects of glorious triumphs, so Propertius himself sticks to his lesser field, and thereby wins glory to the extent that his supposed 'patron' does. In 23-30 the poem explores Maecenas's nature (humility, and unwillingness to pursue the manifestations of power). Verses 31-4 indicate that this way of life will confer fame on Maecenas too: despite his aloofness from public office he will equal the likes of Camillus, be spoken of by the public, share in Caesar's fame and have, in his reputation for loyalty and trustworthiness, the equivalent of a victor's trophies. From 37 Propertius announces that he will not write epic, but love poetry, and hopes for fame from that.

non flebo in cineres arcem sedisse tepentes

Cadmi nec septem proelia clade pari;

nec referam Scaeas et Pergama, Apollinis arces,

et Danaum decimo uere redisse rates

moenia cum Graio Neptunia pressit aratro uictor Palladiae ligneus artis equus.

inter Callimachi sat erit placuisse libellos et cecinisse modis, Coe poeta, tuis.

haec urant pueros, haec urant scripta puellas, meque deum clament et mihi sacra ferant.

te duce uel Iouis arma canam caeloque minantem Coeum et Phlegraeis Oromedonta iugis;

At 47 the address of Maecenas is resumed rather awkwardly, through a mere te duce: one expects a vocative, or a $t u$ in such contexts. And he says, he will write epic after all-if Maecenas shows the way. But there is no expression of the necessary antithesis between this and what precedes, no Latin equivalent for my after all. I conclude therefore that there is a lacuna between 46 and 47.

Lachmann found here a home for the poem's final couplet (59-60), which certainly has its own difficulties.

hoc mihi, Maecenas, laudis concedis, et a te est quod ferar in partis ipse fuisse tuas.

As the poem is transmitted, 59-60 are preceded by 22 verses referring to the future by means of future indicatives, subjunctives and imperatives. Yet it offers a description of present circumstances ('you grant me this element of praise, Maecenas') that (given hoc) needs to pick up an idea from what precedes, and provides no adverb or conjunction to mark a contrast or a resumption of earlier thought. Immediately after verse 46 hoc ... laudis would have something to refer to, but it would be surprising that Propertius should pray for the worship of lads and lasses and then assert (without any marker of contrast) that Maecenas is already offering it. It is rather verses 57-8 that should be transposed: in tu they have a marker of the fresh appeal to Maecenas, and of a new sequence of thought as well ${ }^{31}$. From 43 the text would then read:

inter Callimachi sat erit placuisse libellos et cecinisse modis, Coe poeta, tuis.

haec urant pueros, haec urant scripta puellas, 45 meque deum clament et mihi sacra ferant. mollia tu coeptae fautor cape lora iuuentae

${ }^{31}$ Often $t u$ in marking a new paragraph is accompanied by at or tamen or quoque; but sometimes it functions alone: cf. 2.19.27. 
dexteraque immissis da mihi signa rotis;

te duce uel Iouis arma canam caeloque minantem

Coeum et Phlegraeis Oromedonta iugis;

celsaque Romanis decerpta palatia tauris

ordiar et caeso moenia firma Remo, ...

The transposed couplet asks for Maecenas's guidance for the poetic career already begun (coeptae, immissis), a career that is elegiac (n.b. mollia). dextera signa would be given by a change in direction in Maecenas's own mode of life. This would lead well into verses 47-56, which, as we have seen, promise even to write an epic if Maecenas gives a lead. Given the argument of the earlier portion of the poem, this would be by taking on formal imperium: in context a virtual adynaton.

The problems of the final couplet are then to be solved not by transposition, but by introducing an adversative; for hoc, read nunc (each reduced to a single letter plus suspension in regular abbreviations); and for laudis, laudes. 'If you lead I shall write an epic. As it is, Maecenas, you grant me honour, and it is thanks to you that I am actually said to have joined your party.' The close thus takes us back to 21-2:

at tua, Maecenas, uitae praecepta recepi, cogor et exemplis te superare tuis.

Because this is the path he has chosen, the love elegist who declines to aim for a grander genre can claim to imitate the authority of Maecenas. In that sense, he belongs to the Maecenas party—but not perhaps in any other.

Does this poem tease Maecenas, one might ask, or the common reader? The problem with the former is that we have only the refusals, only the mocking; we have from Propertius no invitations, no expressions of thanks, no revelation of change of heart, no celebrations of what seems to have mattered to Maecenas. A relationship that consists only of refusals can hardly be characterized as amicitia or patronage. ${ }^{32}$ It seems appropriate therefore to try to read this relationship as one that continues the political antipathy implied by 1.21-2. Can we make sense of 2.1 (to return to that point) as a parody of contemporary panegyric? Are there elements in the text that imply disdain, distance or downright opposition?

Let us start with the very first couplet in which Maecenas is named (2.1.17-18):

quod mihi si tantum, Maecenas, fata dedissent,

ut possem heroas ducere in arma manus.

Of all the ways to express natural capacity, Propertius chooses one that involves a verb of giving: he hasn't, he says, been given enough to be able to write an epic. Now we could think that Maecenas has given plenty, and it is simply in contrast to that that the Fates are lacking in beneficence towards him. But we are reading a poem from a writer who has declared his antipathy towards Caesar and the political world, and it is not an obvious conclusion that any gift has come his way; nor will he provide evidence later to confirm that Maecenas has been his benefactor. We may contrast the openness of Horace's proclamations at Epod. 1.31-2:

satis superque me benignitas tua

$$
\text { ditavit; }
$$

Carm. 2.18.11-14:

$$
\text { nihil supra }
$$

${ }^{32}$ Cicero' Laelius makes clear the levels to which acquiescence in the request of an amicus was expected to go, when he illustrates the limits by arguing that one should not follow a friend into treason: am. 33-40. 
deos lacesso, nec potentem amicum

largiora flagito

satis beatus unicis Sabinis;

and Carm. 3.16.37-8:

importuna tamen pauperies abest,

nec, si plura uelim, tu dare deneges.

On the other hand, Propertius's address to Maecenas is a powerful jab if we read it as the opening gambit of an opponent who is aware of the enormous wealth that has been showered by the regime on those writers willing to write sympathetically. ${ }^{33}$ Given the knowledge of the Aeneid revealed in 2.34, we may suspect that Propertius already knows the first word of the major poem Maecenas is buying with his gifts. But he combines arma with manus, in a suggestive evocation of the indecent juxtaposition in book 1, scandalously censored by Goold and others (1.3.16):

et, quamuis duplici correptum ardore iuberent

hac Amor hac Liber, durus uterque deus,

subiecto leuiter positam temptare lacerto

osculaque admota sumere et arma manu. ${ }^{34}$

When he moves on from the list of epic subjects he would avoid even if he could tackle the genre, and turns to the topics of Augustan greatness, it is no surprise that Perusia appears once again (29: euersosque focos antiquae gentis Etruscae) or that at other points too the enthusiasm is more muted than the regret (27: ciuilia busta, Philippos). Gurval has well explored the unease that is manifest in these lines. ${ }^{35}$ There is further reminiscence of the Epodes too: Maecenas is woven into the history of Actium by Horace's versions of the preparations (Epod. 1) and the battle (Epod. 9). In the opening lines of the book he undertakes to support Maecenas as Maecenas supports 'every danger for his Caesar':

Ibis Liburnis inter alta navium, amice, propugnacula, paratus omne Caesari ${ }^{36}$ periculum subire, Maecenas, tuo:

quid nos, quibus te vita sit $^{37}$ superstite, iucunda, si contra, gravis?

utrumne iussi persequemur otium non dulce, ni tecum simul, an hunc laborem, mente laturi decet qua ferre non mollis viros?

feremus, et te vel per Alpium iuga inhospitalem et Caucasum

vel occidentis usque ad ultimum sinum forti sequemur pectore.

We may note how Horace's willingness to travel contrasts with how Propertius has refused his supposed patron in 1.6. And the elegist hits off the Caesari tuo with his tui ... Caesaris (25), and omne periculum with his illis semper ... armis (35):

${ }^{33}$ R.O.A.M.Lyne gives a useful account of the evidence for Horace and Vergil at Horace: behind the public poetry (New Haven, 1995), 9-11.

${ }^{34}$ I have discussed this at LCM 17 (1992), 59-60.

${ }^{35}$ R.A.Gurval, Actium and Augustus (Ann Arbor, 1995), 167-79.

36 Caesari p²: Caesaris cett.: see C.O.Brink, PCPhS 28 (1982), 34.

${ }^{37}$ sit Aldus: si codd.: for references see E.Kraggerud, SO 80 (2005), 45. 
bellaque resque tui memorarem Caesaris, et tu

Caesare sub magno cura secunda fores.

nam quotiens Mutinam aut, ciuilia busta, Philippos

aut canerem Siculae classica bella fugae,

euersosque focos antiquae gentis Etruscae,

et Ptolemaei litora capta Phari,

aut canerem Aegyptum et Nilum, cum tractus in urbem

septem captiuis debilis ibat aquis,

et regum auratis circumdata colla catenis,

Actiaque in Sacra currere rostra Via,

te mea Musa illis semper contexeret armis, et sumpta et posita pace fidele caput.

The catalogue ends with some arresting diction: 'peace [instead of arms] taken up-and laid aside'. Already the poet foresees what will be an important political theme in subsequent books: the persistence of war in this so-called golden age, which separates husbands from loving wives, Postumus from Aelia Galla in 3.12, Lycotas from Arethusa in 4.3, in a striking exhibition of government that is not 'joined up'.

In 17ff it is implied that Maecenas has asked Propertius to produce an epic. Having imagined writing such a work if only the Fates, or perhaps a rich patron, give him more, the elegist points out that it is not in his nature to thunder any more than it was in Callimachus's (39-42); he is a lover and any battles he gets to grips with are those fought in his narrow bed (45). But he goes on to reveal that his love will last till death and beyond, so the denial is made permanent: his poetry will always remain concerned with amor. The poem thus ends with a scene drawn from sepulchral epigram, as the poet at last envisages contact with his 'patron', but only 'by chance' (forte, 75), and after death (71-2). Verses 73-4 are the height of Propertius's encomium:

Maecenas, nostrae spes inuidiosa iuuentae, et uitae et morti gloria iusta meae.

Once again the similarity to other material allows us to find parody ${ }^{38}$, and this is exacerbated by the excess and vagueness of the phrasing: in what sense is Maecenas 'rightful glory for the poet's life and death'? The dative is slightly surprising here; the line has been cited with the normalising mortis $^{39}$, but this hardly helps to clarify the meaning. Even though gloria iusta is found in Cicero (Pis. 57) and elsewhere, I am tempted to print the iuncta of Guietus. One might compare 3.9.33 Caesaris et famae uestigia iuncta tenebis.

But the really disturbing word here is inuidiosa. The Callimachean representation of Pthonos as all that is inimical to poetry and good aesthetic judgement makes this a surprising intrusion in an encomiastic passage. But the effect is much heightened when we consider the meaning of the adjective. OLD lists three senses:

1 'Arousing hatred, unpopular, odious, invidious'.

2 'Arousing envy, enviable'.

3 'Jealous, envious'.

\footnotetext{
${ }^{38}$ Hor. Carm. 1.1.1-2 Maecenas atavis edite regibus,/ o et praesidium et dulce decus meum; Hor. Carm. 2.17.3-4 Maecenas, mearum/ grande decus columenque rerum; Hor. Carm. 3.16.20 Maecenas, equitum decus; Verg. Geo. 2.39-41 tuque ades inceptumque una decurre laborem,/ o decus, o famae merito pars maxima nostrae, Maecenas, ....

${ }^{39}$ By Torrentius in his 1608 edition of Horace.
} 
Only the second has any positive connotation, and when we examine the usages cited here and in the equivalent section of $T h L L$, we find, especially in the earlier examples, that this positive element is almost overwhelmed by a sense of destructive competitiveness:

Cic. Phil. 5.50 Quid enim stultius quam inutilem potentiam, invidiosas opes, cupiditatem dominandi praecipitem et lubricam anteferre verae, gravi, solidae gloriae?

Ov. met. 4.795 (an obvious reworking of the Propertian line) multorumque fuit spes invidiosa procorum/ illa.

Ov. her. 7.120 urbem constitui lateque patentia fixi/ moenia finitimis invidiosa locis./ bella tument.

It seems the most flattering interpretation of the line is to take it as meaning that the young of Rome have such hopes of the favour of Maecenas that they fight to gain it (one thinks of Satires 1.9). I cannot see any case here for supposing that Propertius has reneged on his family's political past and adopted or approached Maecenas as actual or potential patron. And there is, for me, a convincing story to be read here about an ongoing rejection of the various faces of the Augustan regime. We can take delight in the closing lines, for example, when we notice the adroit way in which the tables have been turned on Maecenas (2.1.75-8):

si te forte meo ducet uia proxima busto, esseda caelatis siste Britanna iugis,

taliaque illacrimans mutae iace uerba fauillae:

'Huic misero fatum dura puella fuit.'

The aspiring patron has been presented as hoping for an epic from Propertius; but the poet now in turn instructs him. Maecenas is to weep like an elegist (77) and in 78 to utter a pentameter that combines those two most elegiac themes, love and death.

My foundations are laid: 1.21-2 present to the reading public a Propertius whose remembered origin is antipathetic to Augustus. In addressing 2.1 to Maecenas he makes us ask whether his political attitude persists, along with his erotic compulsion. It does; and the rest of the poetry is to be read with this established persona in mind. He is quintessentially the lovepoet, ill-disposed to the political life and not least to the regime that now dominates Rome's politics.

\section{Propertius 2.7}

The next manifestly political poem, at any rate in the sadly mangled version of book 2 transmitted to us, is 2.7. This begins from Cynthia's joy over the abrogation of a law that threatened to separate her and Propertius. Like 1.21 this has given rise to markedly opposed interpretations, from Cairns ${ }^{40}$ this time and Stahl ${ }^{41}$ once more. Cairns sees the persona adopted by the poet as so anti-social that the reader has to reject any views espoused in the poetry. Stahl finds here a reasoned attack on the intrusion of the regime into the private sphere, and a celebration of the acknowledgement that Caesar's power is limited. Subsequently Gale has argued that both interpretations are not only possible, but right: the poem demonstrates the ambiguity that is essential to elegy.

${ }^{40}$ F.Cairns, 'Propertius on Augustus' Marriage Law (2.7)', GB 8 (1979), 185-204.

${ }^{41}$ Stahl, 139-55. 
But I shall approach the poem primarily through Badian's attempt to show that the 'marriage law' is a 'phantom'. ${ }^{42}$ He points out that there is no other evidence for Augustan legislation to encourage marriage as early as 28 or 27 , and argues that if such measures had been introduced but rejected thanks to opposition we would hear of it. There had in the past been taxes levied on bachelors, and he suggests that this would have been an obvious policy for the triumvirs to introduce in the 30s in an effort to raise money. Appian tells us (Civil War 5.130) that Caesar cancelled the taxes owing when he returned from overcoming Sextus Pompeius in $36 ;{ }^{43}$ Badian imagines a similar announcement in the 20s, cancelling taxes imposed in the lead up to the campaign against Antony; he points out that Propertius's noncompliance might have been based on the hope that a similar amnesty would follow any later bachelor tax. Tacitus, Annals 3.28 gives good warrant for such an annulment:

sexto demum consulatu Caesar Augustus, potentiae securus, quae triumviratu iusserat abolevit deditque iura quis pace et principe uteremur. acriora ex eo vincla, inditi custodes et lege Papia Poppaea praemiis inducti ut, si a privilegiis parentum cessaretur, velut parens omnium populus vacantia teneret.

This is in itself a very plausible reconstruction, though I think Badian is overconfident in claiming that we would know about opposition to a marriage law. It is true that the discussion of opposition in Suetonius (Aug. 34) refers to a later occasion, presumably the events leading up to the lex Papia Poppaea in A.D. 9, given the reference to the children of Germanicus, displayed to the crowd as an example; but the nature of the biography (as of other accounts) is to be selective, and it is hard to believe that this open display of opposition had been preceded by no earlier disquiet over such measures.

And of course Propertius shows us that there had been disagreement. Badian does not return to the poem and think about what it means for the reception of the Triumviral law. The lex is not presented by Propertius as the responsibility of the 'triumvirate', but (verse 5) as an attempt by Caesar to interfere in private life by imposing marriage. Badian's paper wonderfully occludes the fact that Caesar was himself one of the triumvirate, and the one who was active in Rome and who needed money in the mid to late 30s (his period as triumvir apparently lapses at the end of 33): note the singular iusserat in the Tacitus passage. Though the princeps may have seen a need to break from his past, and to put his legislation on a firmer footing than his power as a triumvir will have brought, the public is unlikely to have felt any great distinction between the acts of Caesar in the 30s and those in the 20s; Propertius' poem makes it clear that he at least does not differentiate in the way Badian does. $^{44}$

Again Badian treats the law as simply a matter of taxation. But any tax that discriminates is also an interference by the state in behaviour. ${ }^{45}$ Propertius stresses the effect on him as a lover; as we would expect, he does not discuss the alternative, the financial implications of paying the tax (if that is indeed the sanction involved in the lex he discusses). This fits the nature of his poetry, and it involves exaggeration to the extant that it ignores the choice he

42 E.Badian, 'A phantom marriage law', Philologus 129 (1985), 82-98.

${ }^{43}$ Badian points out that Propertius's non-compliance might have been based on the hope that a similar amnesty would follow any later bachelor tax.

${ }^{44}$ So too Stahl, 342 n.5.

${ }^{45}$ A.Wallace-Hadrill, 'Family and inheritance in the Augustan marriage laws', PCPhS 27 (1981), 58-80, shows that there were other issues involved as well, at least in the later legislation: an attempt to control the transmission of wealth through inheritance as a means of fostering social stability. 
could make, i.e. to pay up-marriage and a continuation of his idealised union with Cynthia is clearly as unthinkable as marrying her would be. It is unlikely that there would be no effect on behaviour from such legislation, and what we know about the later Augustus suggests that he would have been interested in promoting marriage as well as raising tax. Indeed Propertius's poem responds not so much to the tax, as to the arguments that an Augustus is likely to have deployed in introducing it. If he could at some point read to the senate or publish at large Metellus Macedonicus's speech of 131, which proposed compulsory marriage in order to stimulate the birth-rate (Suet. Aug. 89.2), why should we imagine he had no interest in such topics in the late 30 s? ${ }^{46}$ When Propertius moves on from his preference for death over abandoning Cynthia, he asks unde mihi patriis natos praebere triumphis? This move seemed so unexpected a development that the manuscripts actually mark a new poem at this point, though modern editors are virtually unanimous ${ }^{47}$ in continuing here. But if Caesar has been sounding off about the need for marriage and an increase in the birth-rate for Roman citizens, while introducing taxes that penalise those who need to be pushed in the moral direction, the sequence is easy to follow; and so is the further twist that announces nullus de nostro sanguine miles erit: the traditional reason for state-sponsorship of childrearing was to provide soldiers for the army. We should know from modern politics that reactions to new laws respond not to the precise terms of the legislation so much as to the debate engendered by the introduction of the law, and that debate depends on the ways the governing regime tries to commend the new measures to the public, and how it is perceived in general.

We have a puzzle then, if Badian is right that the marriage law is a 'phantom': how does it happen that Propertius is so prescient in his response to Augustus's later marriage legislation and the arguments he deployed in support of it? There has been one notable attempt at a solution: like Alexander with the Gordian knot, Beck ${ }^{48}$ cuts right through the problem by concluding that the poem is a later addition to the book by a different author; though he reviews the poem looking for evidence that it is post-Propertian in style and diction, he finds nothing cogent, however, and he does not present any plausible theory for the poem's transmission here. So there is a problem still to be solved, and unless someone does so, it seems reasonable to conclude that 2.7 is a response to a law that penalised bachelors, and perhaps also the childless.

Of course, we should note that the poem celebrates the abrogation of the law. A proAugustan reader might argue that as Augustus has himself instigated, or at least acquiesced in the change, Propertius cannot rationally complain about him. But this is to ignore the phrasing of the piece. Caesar is mentioned only during consideration of the threat that the law posed (ni nos diuideret, 3). He is implicitly compared with Jupiter, with the superficially flattering implication that he might prove successful where Jupiter has to yield. ${ }^{49}$ This is an

\footnotetext{
${ }^{46}$ A.Barchiesi ('Allusion and society: Ovid the Censor', AJAH 13 (1997), 96-105 = Speaking volumes (London, 2001), 155-9) has shown that Augustus' version of the speech was given before Ovid wrote Amores 3.11.38-9.

${ }^{47}$ Phillimore is an exception, in the 1901 OCT. There is conceivably a lacuna, however, as Lachmann suggested.

${ }^{48}$ M.Beck, 'Properzens Elegie 2,7 und die augusteische Ehegesetzgebung', Philologus 144 (2000), 303-24.

49 This theme returns in 3.11, where Jupiter is the climactic example of a powerful male who has yet been forced to submit to a female (Iuppiter infamat seque suamque domum). Propertius then goes on to consider the example of Antony, who submitted to Cleopatra.
} 
aspect that Cairns fails to take into account in his discussion. He argues that the poem displays itself as a parody of a proper attack on a law by its half-hearted treatment of the rhetorical norms. Of the four headings under which an attack might be mounted (legality, justice, utility and possibility), Cairns finds only arguments concerning possibility in 2.7. This is a feeble analysis even on its own terms: a law that has been abrogated is no longer legal, so the poem starts with a decisive point under the first of the headings. When Propertius goes on to point out that no soldiers would be produced from his blood (13-14), he is attacking an aspect of the measure's utility. Nor does Cairns put the other part of his argument on a firm foundation. It is right that an Augustan sympathiser could read the poem and come away with his views strengthened on the grounds that anything said in the voice of the Propertian persona is to be disdained as anti-social; but this will be true of any text, that a determined reader can go against the grain, and there is no sign that this was the intention of the poet. More than most poets Propertius stresses the whole identity of poet and lover, and Cairns does not unpick this or show how the role is a parody.

For Cloud ${ }^{50}$ the poem is a rhetorical exercise with no interest in the political realities of the day: Propertius's fame has no more reached the Ukraine than has the empire ruled by Augustus; ${ }^{51}$ and the law could not have separated the lovers against their will. I have already shown reason for finding political reality here; but there are additional problems with this analysis. Cloud bases his argument for Propertian insincerity on the existence of a descendant, Passennus Paulus (Pliny, ep. 6.15.1, 9.22.1): the poet cannot have meant what he said about being unwilling to marry or have children. This pays insufficient attention to the text: verses 13-14 only say that Propertius could not father soldiers (and as his descendant is known to Pliny as a poet, he is hardly evidence against the claim!). More seriously, as a statement of opposition to enforced marriage, 2.7 does not depend on biographical truth, any more than Ovid's later protest against the high-handed relegation of Roman citizens requires him actually to have been sent to Tomi himself. A final point is not considered by Cloud (and this is not untypical of the way in which poetic and prose sources are commonly used): the one who is exaggerating may be Passennus Paulus himself. In selling himself as a poet, he could well have been tempted to claim direct descent from the famous Propertius, who was actually, say, his great-grandfather's cousin.

Gale essays a more sophisticated interpretation. ${ }^{52}$ She notes with surprise the variety of interpretations of 2.7. But we should not be surprised: this is an obvious challenge to proAugustan readings of the poet, and an equally obvious foundation for anti-Augustan readings, so it is inevitably a centre for controversy. She finds attractions and deficiencies in the theses of both Cairns and Stahl; and argues that this poem shares in the general and strategic equivocations in the treatment of the militia amoris. The poet is neither 'Augustan' nor 'antiAugustan', but interested in presenting ambivalences to the reader. We are invited to decide

However, there was another man who did not submit, even to Cleopatra: uix timeat saluo Caesare Roma Iouem (3.10.66): the princeps is something beyond the human, and the divine; beyond belief indeed. See also the discussion below.

${ }^{50}$ D.Cloud, 'Roman poetry and anti-militarism', in J.Rich \& G.Shipley (edd.), War and society in the Roman world (London, 1993), 113-38.

${ }^{51}$ Modern denials of the poets' claims about the extent of their readership should at least acknowledge the discovery of the Gallus fragment at the boundaries of the empire; there were of course special circumstances.

${ }^{52}$ M.R.Gale, 'Propertius 2, 7: militia amoris and the ironies of elegy', JRS 87 (1997), 77-91. 
which parts are sincere ${ }^{53}$ : what we find will depend on our own presuppositions, as the author has not provided 'enough authorial guidance to force the issue' (86). As should be clear, I believe he has given adequate guidance, through the prior position of 1.21-2 and 2.1, and in 2.7 itself.

Though I take issue with many aspects of the paper, I should acknowledge that it offers much impressive insight into the use of militia amoris. ${ }^{54}$ However, when in discussing 2.15 and 2.16 Gale says (p. 82) 'We can take him [i.e. Propertius] either to be mocking the conventions of Augustan panegyric, or to be satirizing the pretensions of his own personathe rebellious youth, who thinks the world well lost for love,' there is no acknowledgement of the extent to which the latter is reading against the grain of the text; the whole persona must be constructed as a satire. ${ }^{55}$

The poems say much about the misfortunes of love for Cynthia, but whenever the lover's life is set against an alternative, it is presented as Propertius' ideal, not something to be avoided, at any rate by the elegist. A striking instance of this comes in 1.6, cited by Gale as a prime piece of evidence. She quotes, but ignores, his clear indication of choice in verses 27-8: multi longaeuo periere in amore libenter, in quorum numero me quoque terra tegat.

Though 'love is viewed simultaneously through the eyes of the obsessed lover and of an ideology which condemns such obsession as diametrically opposed to the duties and rewards of public life' (81), there is no doubt where the poet's enthusiasm lies; there is no mockery directed at 'the pretensions of his own elegiac persona'. As Gale herself puts it (88), 'amor ... is both supremely desirable, and supremely painful'.

Gale puts a good deal of weight on the notion that Propertius marks his views as unacceptable by choosing as his audience conventional figures (82-3). The idea is not sustainable, however: there are far more poems addressed to Cynthia than to Tullus and Maecenas; Bassus (who praises many girls) is hardly to be grouped with that pair; Gallus, who receives as many poems in Book 1 as Tullus, is a thoroughly eroticized figure (whether or not we identify him as the elegist); and the poet makes it clear repeatedly that he foresees an audience very different from those to whom the initial poems of Books 1 and 2 are addressed. ${ }^{56}$ Already at $1.7 .13-14$, the reader is presented as someone other than the epicwriting addressee, Ponticus:

me legat assidue post haec neglectus amator, et prosint illi cognita nostra mala.

\footnotetext{
${ }^{53}$ However, it is (I believe) a serious misreading of Stahl to say that he finds irony in 2.7.1-6; rather he takes the elevation of Augustus over Jupiter to mark an implicit infringement of citizens' rights. There is truth in at magnus Caesar, but it is not a flattering truth, and the greatness is immediately qualified: sed magnus Caesar in armis.

${ }^{54}$ One particularly fine formulation (as long as 'accepts' means 'accepts as a fact' or even 'tolerates', but not 'welcomes') is the following (84): 'On the political level, the poet both accepts and refuses to celebrate the status quo.'

${ }^{55}$ My position here has something in common with that of R.Mayer, 'Persona $<\mathrm{l}>$ problems. The literary persona in antiquity revisited', MD 50 (2003), 55-80.

${ }^{56}$ Moreover, Tullus can be seen as chosen for address as a figure who in his conventional attitudes is in contrast with Propertius himself: besides what is said above, see

R.O.A.M.Lyne, PCPhS 44 (1998), 160-6 on Tullus in 1.1.
} 
And in verses 23-4 iuuenes salute the poet's tomb with disbelief, and admiration at his expression of their feelings:

nec poterunt iuuenes nostro reticere sepulchro:

'ardoris nostri magne poeta, iaces?'

At 3.3.47-50 he is instructed by Calliope to sing what will help lovers to trick husbands.

puellae are shown responding to his poetry at 2.34.57-8, where they treat him as rex in their symposium, and at 3.3.20, where Propertius is what the lonesome girl chooses to read while she is waiting for her man to turn up. It is hard to see any basis for the claim 'the audience is characterized, by and large, as hostile to ... the ideas the poet proclaims' (83). Even 2.1, the poem of apparent dedication to Maecenas, begins with an address to a plural readership (Quaeritis ...?): they are there before the 'patron', they are figured as having already read previous work, and they are thus in a position to interpret Maecenas against the background that has been established by book 1 .

Gale's analysis of 2.7 itself starts by setting against each other 'the images of the lover as a degenerate idler and as a heroic figure' (85). There is nothing in the poem about idling or degeneracy, nor can I find the 'feeble, womanish figure' she descries in verses 8-14 (88):

nam citius paterer caput hoc discedere collo quam possem nuptae perdere amore faces, aut ego transirem tua limina clausa maritus, respiciens udis prodita luminibus.

ei mihi, tum quales caneret tibi, Cynthia, somnos, ${ }^{57}$

tibia funesta tristior illa tuba!

unde mihi patriis natos praebere triumphis?

nullus de nostro sanguine miles erit.

Against Stahl, who wants unde to be rendered 'why', verses 13-14 are rightly understood by Gale to mean 'How am I to provide sons for my country's triumphs? There will be no soldier from my blood'. However, I cannot find 'obliging despondency' here, but a confident statement of genetic fact. Verses 15-16 should scotch any reading that attributes the unmilitary nature of Propertian offspring to their father's weakness:

quod si uera meae comitarem castra puellae, non mihi sat magnus Castoris iret equus.

The picture Gale implies is of a Propertius who has no commitment to personal freedom ${ }^{58}$ or to the Augustan regime, but who wants the reader to engage with the ironies of his text as if there might be a committed position behind them. When she argues that the text is not univocal, this is of course right: texts aren't. But I do not share her view ${ }^{59}$ that this is an alternative to choosing between Stahl and Cairns. What sort of author is she conjuring up? One who is undecided whether or not it is good for the state to interfere in the marital status of its citizens, and whether or not Augustus really is greater than Jupiter? Cairns' interpretation seems to me more probable than that.

\footnotetext{
57 The main manuscripts read a mea tum quales caneret tibi tibia somnos; the correction Cynthia is already in P.

${ }^{58}$ We may note 1.1.28, sit modo libertas quae uelit ira loqui, a verse of some political edge from an opponent of the regime.

${ }^{59}$ And that of Miller 143-6 (which makes no acknowledgement of Gale).
} 


\section{Other political poems in books 2 and 3}

In the remainder of our books 2 and 3, Propertius at times suggests a movement towards support for the regime, with panegyrical material promised or briefly provided. But regularly there is an underlying tone of cynicism and disdain, and always there is a return to the norms of individualism. A brief survey will have to suffice in this part of my examination of the corpus. ${ }^{60}$

Poem 2.10 tells us that the poet is giving up writing about Cynthia: that work is complete and he will now turn to epic (7-8):

aetas prima canat Veneres, extrema tumultus;

bella canam, quando scripta puella mea est.

In direct contradiction of 2.7.15-16, he promises to follow the castra of Augustus (15-20):

India quin, Auguste, tuo dat colla triumpho,

et domus intactae te tremit Arabiae;

et si qua extremis tellus se subtrahit oris,

sentiat illa tuas postmodo capta manus!

haec ego castra sequar; uates tua castra canendo

magnus ero: seruent hunc mihi fata diem.

In itself this could mark a startling change of direction; but the promised move is never made. The following poems, which have been seen as opening the original third book, with 2.10 closural in its own collection, continue to sing of Cynthia. In particular, 2.13 begins as if it might tell of military adventures, before Amor in the pentameter puts the arrows to erotic purpose:

Non tot Achaemeniis armatur Itura ${ }^{61}$ sagittis spicula quot nostro pectore fixit Amor.

The puella is still being sung; he has not changed camp; bella will have to wait a while. By the time we reach 3.5.19-26, the poet is no longer promising to produce panegyric or epic, but (even more implausibly) ${ }^{62}$ natural philosophy:

me iuuat in prima coluisse Helicona iuuenta

Musarumque choris implicuisse manus;

me iuuat et multo mentem uincire Lyaeo

et caput in uerna semper habere rosa.

atque ubi iam Venerem grauis interceperit aetas

sparserit et nigras alba senecta comas,

${ }^{60}$ I have discussed some relevant passages in earlier publications. 'Ars moratoria (Ovid, A.A.1.681-704)', LCM 17 (1992), 59-61 touches on 2.16.41-2, and argues that the couplet is either a scurrilous double entendre or an interpolation (on grounds of irrelevance to context and inelegant use of Ovidian phrasing); 'Some allusions to Callimachus in Latin poetry', $M D$ 33 (1994), 51-79 examines 2.31 (though without judgement on the tone of the flattery) and 4.6 (which I see as exploiting its similarity to the Callimachean Hymn to Apollo to bring out the ironies of an elegiac celebration of military victory in a period of never-ending warfare); 'Propertius: division, transmission, and the editor's task', PLLS 8 (1995), 165-85 examines the relationship between 2.10 and 2.13 on pp. 166-8.

${ }^{61}$ armatur Etrusca w, which makes no sense; there are other plausible conjectures to similar effect such as armantur Susa (I).

${ }^{62}$ Cf. Vergil, a far more philosophical writer, on his incapacity for the Lucretian mode, at Geo. 2.483-94. More generally on the use of natural philosophy as a potential topic, see D.C.Innes, CQ 29 (1979), 168-71. 
tum mihi naturae libeat perdiscere mores,

quis deus hanc mundi temperet arte domum; ...

This is a striking denial of any intention to carry out the programme apparently promised in 2.10: maturity will not bring a move to Augustan poetry, but to a long list of questions fit for a poem de rerum natura.

In 3.3 the poet dreams of writing an Ennian epic, but his fantasy is summarily dismissed by first Apollo, and then Calliope. The first poem of the book has already indicated the continuation with elegiac and thus erotic themes (3.1.15-20): ${ }^{63}$

multi, Roma, tuas laudes annalibus addent, qui finem imperii Bactra futura canent.

sed, quod pace legas, opus hoc de monte Sororum detulit intacta pagina nostra uia.

mollia, Pegasides, date uestro serta poetae: non faciet capiti dura corona meo.

quod pace legas is especially mischievous. When the Gates of War in Bellona's temple are being closed ${ }^{64}$, the era is pronounced as an age of pace: what need then of military epic? Doubts about the peace of the age are implicit in 15-16 (which forecast prophecies that Bactra will be conquered, not the conquest itself); they are confirmed by $3.4,{ }^{65}$ with its initially excited response to the news that Augustus is planning an attack on the Indians (3.4.1-2):

Arma deus Caesar dites meditatur ad Indos, et freta gemmiferi findere classe maris.

However, even in the setting up of the situation there are notes that detract from the glorious ${ }^{66}$ opening Arma deus Caesar. The emphasis on wealth (dites, gemmiferi) is continued in the following couplet (magna ... merces, 3). In urging on the ships and cavalry, the peaceable poet stresses that they are experienced in war, this is a customary function (3.4.7-8):

ite agite; expertae bello, date lintea, prorae; ad solitum, armigeri, ducite munus equos.

Though he claims to be singing omina fausta (3.4.9), the very next words are as ill-omened as could be:

omina fausta cano: Crassos clademque piate.

Both the disaster at Carrhae and the greed that forces men into foreign adventures will be touched on in the next poem. The second half of 3.4 looks forward to a spoil-laden triumph, but glorious though the vision may be, the poet stresses his own distance from the grandeur of the celebration (3.4.15-16, 21-2):

inque sinu carae nixus spectare puellae incipiam et titulis oppida capta legam. ...

praeda sit haec illis quorum meruere labores: mi sat erit Sacra plaudere posse Via.

${ }^{63}$ On 3.1-5 generally, see W.R.Nethercut, AJPh 91 (1970), 385-407.

${ }^{64}$ As Augustus proudly announces in Res gestae 13; cf. also Verg. Aen. 1.293-6, 7.601-22.

${ }^{65}$ On 3.4, see L.P.Wilkinson, in Studi in onore di L.Castiglioni (2 vols., Florence, 1960), 1091-1103.

${ }^{66}$ Glorious, but 'almost offensive in its casualness': C.O.Brink, Horace on poetry: epistles book 2 (Cambridge, 1982), 543, reprising the judgement of M.Hubbard, Propertius (London, 1974), 104-5 (she goes on to brief accounts of 3.5, 3.11-12 to which mine are much indebted). 
For him the triumph will mean a chance to be in the crowd with his darling; ${ }^{67}$ far from writing a poem to mark the triumph he will idly read the tituli on passing wagons while leaning on the bosom of his girlfriend.

Poem 3.5 begins and ends by recalling the previous poem. Whereas Caesar plans war, Love enjoys peace (3.5.1-4):

Pacis Amor deus est; pacem ueneramur amantes. stant mihi cum domina proelia dura mea; ${ }^{68}$

nec tamen inuiso uictus ${ }^{69}$ mihi carpitur auro, nec bibit e gemma diuite nostra sitis.

The lover concedes that he regularly has epic battles with his mistress; but denies that he is either avaricious or wealthy.' Verse 2 establishes a paradox: the peace of Amor involves battles. What it avoids (3-6) is greed and luxury. Thus a redefinition of pax is realized ${ }^{70}$, and one that is made all the sharper because Caesar's wars have been presented in 3.4 as intended to gain riches. But the most outspoken distancing of the poet from the expansionist policy of 3.4 comes in the closing couplet of 3.5. As in 3.4's final couplet (21-2, quoted above), Propertius opposes his own future (the writing of philosophy) to that of the warmongers (or is it those who in preferring arma prefer the Aeneid?):

exitus hic uitae superest mihi; uos quibus arma grata magis, Crassi signa referte domum.

There is bitter disdain here; and that tone is compounded by the ambiguity of Crassi. Though modern editors print it as a genitive of Crassus, and thus an echo of the supposed omina fausta of 3.4.9, in contemporary script and punctuation it will not have been distinguished from the vocative plural crassi: 'thickheads'. I thus read the opening sequence of book 3 as a strong reassertion of poetical and political opposition to Augustus.

Perhaps the most problematic poem for the anti-Augustan reader is $3.11 .^{71}$ This begins with a statement about the inevitability of the male lover's domination by the female. Though Propertius' subservience is found reprehensible by the unnamed addressee, he can point to heroes, even to gods who have been dominated by women: Jason by Medea, Achilles by Penthesilea, Hercules by Omphale. Semiramis was the builder of Babylon and conquered Bactra; even Jupiter brings disrepute on himelf and his house (3.11.28):

${ }^{67}$ Ovid takes this moment and turns it into didactic in Ars 1.177-228, with a further twist in the triumph scene of Tristia 4.2: I have discussed this passage at PCPhS 41 (1995), 145-9. ${ }^{68}$ This is as close as Propertius comes to collapsing the antithesis between love and war; to do so here allows him to go on and stress a particular aspect of difference- the greed involved in Roman warmongering. ${ }^{69}$ uictus Giardina (MCr 19-20 (1985), 203-4: pectus W.

${ }^{70}$ Compare the comments of Hertzberg ad loc.: 'itaque cum pacis deum Amorem Propertius dixisset, recte tamen addere poterat se quippe cultorem eius dei leuiore illa et, utut dura, innocenti tamen belli imagine in castris puellae contentum esse, recteque pergit: nec tamen etc. haec enim, quae uera belli mala sint, a se procul habere se ait.' Miller (152) notes how the negated gemma of 3.5.4 picks up the gemmiferi ... maris of 3.4.2.

${ }^{71}$ There has been extended discussion by a number of scholars who find anti-Augustan sentiments here: E.Paratore, L'elegia III xi e gli attegiamenti politici di Properzio (Palermo, 1936); R.A.Gurval, Actium and Augustus (Ann Arbor, 1995), 189-208; A.Tronson, 'What the poet saw: Octavian's triple triumph, 29 B.C. Jeremiah Markland's conjectures at Propertius 3.11.52-53', AClass 42 (1999), 171-186. On the other side stands R.M.Lucifora, Voci politiche in Properzio 'erotico': ideologico e progetto elegiaco in II xvi e III xi (Bari, 1999). 
Iuppiter infamat seque suamque domum.

We then move on to a more immediate example: Antony and Cleopatra. Expressions of horror at the wickedness of Egypt, at Cleopatra's monstrosity ${ }^{72}$ and her audacity in challenging Rome lead to despair over the future of the republic, saved only by the triumph of Caesar (3.11.47-50):

quid nunc Tarquinii fractas iuuat esse secures, nomine quem simili uita superba notat,

si mulier patienda fuit? cane, Roma, triumphum

et longum Augusto salua precare diem.

Rome, however, is protected by divine power, just as it was founded by divine power (3.11.65-6):

haec di condiderant, haec di quoque moenia seruant:

uix timeat saluo Caesare Roma Iouem.

Caesar, unlike Jove, did not fall to the sexual power of an extraordinary woman: verse 66 seems something of an understatement. We may recall a verse of the previous book: possum inimicitias tunc ego ferre Iouem (2.13.16, echoed at 2.34.18). Caesar alone is capable of avoiding female domination. ${ }^{73}$ Thus he is almost dehumanized; in his lack of susceptibility to Cleopatra, he is contrasted with the submissive heroes, most directly with Antony, implicitly with his adoptive father Julius ${ }^{74}$; but he reaches the height of sharing with Propertius himself a virtual superiority to the infamous Jupiter. This is an odd sort of panegyric. The achievements of Roman greatness are then reviewed, and belittled in comparison with the victory at Actium $(67-8,59-64){ }^{75}$ The poem does not revert directly to the dominance of women, but ends with Caesar (3.11.69-72):

Leucadius uersas acies memorabit Apollo:

tantum operis belli sustulit una dies.

at tu, siue petes portus seu, nauita, linques,

Caesaris in toto sis memor Ionio.

This alludes to one of the epigrams in the new Posidippus papyrus (39.1-2, 7-8 A.-B.) ${ }^{76}$ :

Kai; mevllwn a\{la nhi; ü pera'n kai; pei'sma kaqavptein

cersovqen, Eujploiai æcai'reæ do;" $\triangle$ Arsinovhi, ...

ei\{neka kai; cersai'a kai; eij;" a\{la di'an ajfieij;" eujca;" euJrhvsei" th;n ejpakousomevnhn.

Arsinoe been replaced by the conqueror of her descendant: Rome learns to treat its rulers as Alexandria treated the Ptolemies. As significant within this poem is that a male leader has replaced a female.

With verse 70 we may compare Ennius 258 Sk. multa dies in bello conficit unus; Lucr. 5.9991000 at non multa uirum sub signis milia ducta/ una dies dabat exitio; Silius 2.5 quos turbine Martis/abstulit una dies. In these the concept of war is present as part of an adverbial limitation, and not as the object of the destructive verb. If belli is taken with una dies,

\footnotetext{
${ }^{72}$ Stahl brings out how the poet plays on the 'official phrasing and thinking' (239) in his condemnation of Cleopatra's attempt to unman Rome.

${ }^{73}$ Dio Cassius 51.12 presents Cleopatra as attempting to sway Caesar emotionally, but he is quite unmoved 'and said nothing affectionate' (mhvte ... ejrwtikovn ti ejfqevgxato, 5.12.6).

${ }^{74}$ On the importance of Julius Caesar for the poem, see Stahl's discussion (240-4 ), and Miller 148.

${ }^{75}$ Memory of 2.15.41-8 tarnishes any Propertian praise of Actium, of course.

${ }^{76}$ See C.Austin \& G.Bastianini (Milano, 2002), ad loc. and G.Hutchinson, ZPE 138 (2002),

5. I am grateful to Sandro Barchiesi for suggesting the allusion might be important.
} 
Propertius's sentence is parallel to the Ennius: 'a single day of war took away so much labour'. tantum operis suggests the greatness of the conflict and the armaments obliterated; it also alludes to 3.3.4, where the phrase has described the mammoth enterprise envisaged by the poet:

Visus eram ...

reges, Alba, tuos et regum facta tuorum,

tantum operis, neruis hiscere posse meis.

A single day of war has destroyed the potential for many military epics. All that is possible now is the composition of Augustan panegyric. As Nethercut saw (TAPhA 102 (1971), 41143) the nautical language of the final couplet recalls that of the programmatic couplets 3.3.23-4, 3.9.35-6: by implication the poet, whatever his genre, is to think of Caesar. The poem that began as a reflection on the poet's relationship with his mistress ends without thought of her, or of anything but the princeps, a movement the opposite to that in 2.31-2. When Rome has such a citizen, consideration of any question leads inexorably to praise of him. However, from the author of 1.21-2 and the other poems of opposition, indeed of the opening lines of this very poem, this is not a surrender, but a defiant statement of the grim truth.

As with 2.10, any residual effect of the panegyric is quickly subverted by another poem. The close of 3.11 has spoken of Augustus's victory as having put an end to war; the sailor is to remember this (we might surmise) because the Ionian Sea is now secure and peaceful. Yet 3.12 presents us with Postumus abandoning his wife Galla and heading east behind the standards of Augustus (3.12.1-2):

Postume, plorantem potuisti linquere Gallam, miles et Augusti fortia signa sequi?

The propaganda of peace is immediately exposed as a myth; in reality the greed of the regime and its supporters separates husbands from wives. We can hardly avoid thinking back to 3.4 when a curse is uttered on all whose avarice promotes war (3.12.5-6):

si fas est, omnes pariter pereatis auari et quisquis fido praetulit arma toro.

A long narration of the adventures of Ulysses (3.12.24-36) is motivated by a comparison between him and Postumus, but there is no implication for Postumus' own role: it is only in his wife's tested fidelity that he is like the epic hero. She is the one who can challenge, and surpass her epic model: uincit Penelopes Aelia Galla fidem (38).

\section{Book 4}

At the end of book 3 Propertius says an apparently final farewell to Cynthia, at last overcome with disgust at her infidelity and deceit, as he presents it (3.24-5). Book 4 begins with something quite different: a vision of how Rome has changed since its humble beginning. This is sometimes read as a statement of declining morality in counterpoint to the rise in material richness. Though there are elements that might be read as having an ethical point, I think such implications have always to be added by the reader. The consistent emphasis in the long opening sequence that compares present and past is the extraordinary, almost unimaginable, difference between the two (4.1.1-36):

Hoc quodcumque uides, hospes, qua maxima Roma est ante Phrygem Aenean collis et herba fuit, atque ubi Nauali stant sacra Palatia Phoebo, Euandri profugae concubuere boues. 
fictilibus creuere deis haec aurea templa, nec fuit opprobrio facta sine arte casa, ...

curia, praetexto quae nunc nitet alta senatu, pellitos habuit, rustica corda, patres;

bucina cogebat priscos ad uerba Quirites: centum illi in prati saepe senatus erat;

nec sinuosa cauo pendebant uela theatro; pulpita sollemnis non oluere crocos.

nulli cura fuit externos quaerere diuos cum tremeret patrio pendula turba sacro; ...

quippe suburbanae parua minus Vrbe Bouillae, et, qui nunc nulli, maxima turba Gabi,

et stetit Alba potens, albae suis omine nata, tunc ubi Fidenas longa erat isse uia.

The scene is a wonderful inversion of Aeneas's tour of Pallanteum with Evander, looking back to the even earlier past and ahead to the Rome that will grow where they walk (Aen. 8.306-69). ${ }^{77}$ As 4.1A precedes, it appears that a version of Callimachus's aetia is what the poet intends in this book, and that this is confirmed by the closing couplets (4.1.67-70):

Roma, faue: tibi surgit opus; date candida, ciues, omina; et inceptis dextera cantet auis:

sacra deosque ${ }^{78}$ canam et cognomina prisca locorum: has meus ad metas sudet oportet equus.

However, the couplet that concludes the opening sequence makes such a reading very problematic (4.1.37-8):

nil patrium nisi nomen habet Romanus alumnus: sanguinis altricem non putat ${ }^{79}$ esse lupam.

Verse 37 voices a stark rejection of the aetiological mode: 'the Roman nurseling has nothing from his forefathers except the name'. This accurately sums up the preceding couplets, but effectively dismisses attempts to link present-day Rome with its origins: the connexions are purely nominal. It is against this background that we must read what follows: before Propertius lays claim to the title Callimachus Romanus (64) he has already undermined the project to which that name is attached.

Verses 39ff. then provide a scornful mimicking of what Propertius sees as the faults of the Aeneid.

huc melius profugos misisti, Troia, penates;

heu quali uecta est Dardana puppis aue!

iam bene spondebant tunc omina, quod nihil illos

laeserat abiegni uenter apertus equi,

cum pater in nati trepidus ceruice pependit et uerita est umeros urere flamma pios.

tunc animi uenere Deci Brutique secures,

${ }^{77}$ See K.W.Weeber, 'Properz IV i 1-70 und das 8.Buch der Aeneis', Latomus 37 (1978), 489506 on this important intertextuality.

${ }^{78}$ So Wellesley (ACD 5 (1969), 96); the manuscripts read diesque, but then this part of the promise is scarcely fulfilled, the Parilia being the only day that gets a mention later in the book.

${ }^{79}$ putat 1 : putet $\mathrm{W}$ : pudet $\mathrm{P}$. There seems no point in a modulation from statement in the hexameter to hypothesis in the pentameter. 
uenit et ipsa, sui Caesaris arma, Venus,

arma resurgentis portans uictricia Troiae:

felix terra tuos cepit, Iule, deos.

The reader has the choice between finding irony here, or in the opening 38 lines. Given a long enough view of history, everything can be presented as for the best (melius, 39: cf.

Aen.11.425-6 multa dies uariique labor mutabilis aeui/ rettulit in melius ${ }^{80}$ ). Vergil continually has his narrative suggest that things were as they were in the heroic past so that not only Rome, but Augustan Rome, can come to be. The arms that Venus brings (46-7) are acutely described by Propertius as belonging to her Caesar — on one reading Aeneas, the proto-Julian, on another Augustus himself, whose victories so dominate the picture on the shield. In Vergil's worldview, as here satirized, all of Roman history is fated, and thus implicit in the moment of Aeneas's escape from Troy: within book 2 we may note the explicit futures of Hector (2.294-5 moenia ... statues) and Creusa (2.781 Hesperiam uenies). Brutus appears in book 6, already (like so many others) with his character and accoutrements defined (6.817-23), and the Decii follow (6.824): note how Propertius picks up various words and notions, and in particular the verse-ending secures/securi in his conjoining of the republican heroes.

uis et Tarquinios reges animamque superbam

ultoris Bruti fascesque uidere receptos?

consulis imperium hic primus saeuasque secures

accipiet, natosque pater noua bella mouentes

820

ad poenam pulchra pro libertate uocabit,

infelix, utcumque ferent ea facta minores:

uincet amor patriae laudumque immensa cupido.

quin Decios Drusosque procul saeumque securi

aspice Torquatum ...

825

It is a marvellously absurd extension of the pageant of Romans to have these figures present not in the Underworld, but already at the moment of Troy's fall. Even funnier is the enthusiastic celebration of the she-wolf (or is it a prostitute?) who nurtures Romulus (55-6):

optima nutricum nostris, lupa Martia, rebus, qualia creuerunt moenia lacte tuo!

Walls grow from her milk: wondrous causality! In 49-52 Propertius turns his attention to other post-factum prophecies of Roman greatness. First the Sibyl of Aeneid 6 and Tibullus 2.5 are combined, then he adds the Cassandra of Lycophron's Alexandra: since the Sibyl and Cassandra have made prophecies about Rome, he too will try his hand at prophecy ${ }^{81}$, and, in referring to the past, his predictions will necessarily be fulfilled. I am reminded of Auden's attack on the Vergilian mode, in Secondary Epic:

No, Virgil, no:

Not even the first of the Romans can learn

His Roman history in the future tense,

Not even to serve your political turn;

Hindsight as foresight makes no sense.

Propertius's closest ever identification with Callimachus comes in verses 63-4:

ut nostris tumefacta superbiat Vmbria libris,

Vmbria Romani patria Callimachi.

${ }^{80}$ A delightfully cynical extension of this view of history comes in Lucan's realization that the civil wars were justified because they led to Nero (1.33ff).

${ }^{81}$ See J.L.Marr, CQ 20 (1970), 162-3 for a similar reading. 
Despite the way in which it has been read, this can hardly be a straightforward piece of programmatic self-identification in a poem where aetiology has been rejected as a false or nominal approach to the past (37-8), and satire is directed at the telescopic hindsight of Vergil, the poet who had spoilt the aetiological mode for elegists (39-56). One might try to read the tag Romanus Callimachus as just a bitter rejection of old allegiances (1.1.1ff., 2.1.40, 3.1.1). But for all its irony the phrasing Vmbria Romani patria Callimachi suggests a parallelism between the two poet: Propertius is a Callimachus when, in a city not his patria, he sings the praises of an autocratic dynasty; Umbria is to Cyrene as Rome to Alexandria. When in 63 he hopes to see tumor brought about by his patriotic project, we should note that it is in conflict with the Callimachean aesthetic, ${ }^{82}$ and condemn what he proposes to build as a folly.

It should be little surprise then that the book's second poem (4.1B) marks a derogation from the promised Aetia: a charlatan called Horos provides some rather underwhelming evidence for his skill in predicting the future, and mines Propertius's past works for information about him. He tries to chill the bones with a hint of a grim future (71), but ends with an impenetrable piece of astrology (4.1.147-50):

nunc tua uel mediis puppis luctetur in undis, uel licet armatis hostis inermis eas, uel tremefacta cauum tellus diducat hiatum, octipedis Cancri terga sinistra time!

'Fear the baleful back of the eight-footed Crab!'. On one level, this must be the mumbojumbo of the astrologer, vague enough to provoke multiple meanings of which one will come to make sense. Even if we acknowledge this, it does not follow that we should accept the advice of Ovid (fast. 1.313 octipedis frustra quaerentur bracchia Cancri) and stop the search for Propertius' meaning. However, if the reference is to Cynthia's birth-sign, or the poet's own, or something similar, then he has left us no clue elsewhere to solving the riddle. Nothing plausible has been found in extant texts. ${ }^{83}$ The most attractive solutions lie in the coins issued by M.Durmius in 19 B.C. These have a crab on the reverse, and a head of Augustus on the obverse (RIC I² Aug.316 + pl.6; CRE I Aug.60 + pl.2.13). Camps (Cambridge, 1965), ad loc., saw an evocation of money, and a warning against a rich rival for Cynthia's affections, Stahl 278-9 (and n.13) a warning against taking the Augustan shilling. The top of the crab is prominent in most representations, and appears in some literary accounts (testudo, 'the shell', is what rises first at Man. 2.199; and cf. Man. 2.510 summi ... fastigia Cancri), but the word terga attracts attention because it is not found elsewhere of the creature or the constellation (contrast the lists given by Shackleton Bailey for terga Leonis, on the one hand, and bracchia Cancri, on the other; Cancri membra would have been an easy alternative here: Ov. met. 2.197 refers to the membra of Scorpius). One possible nuance of terga is 'back', as in the sense 'opposite side' (OLD 1d); on the opposite side of the coins to the crab was Augustus.

82 So too C.Macleod, PLLS 1 (1976), 144-5 = Collected essays (Oxford, 1983), 205-6.

${ }^{83}$ S.D.Kaufhold, Eranos 94 (1996), 29-33 sees an allusion to Verg. ecl. 10.68, where (in imitation of Theoc. 7.113) herding the sheep of the Ethiopians sub sidere Cancri is Gallus's last hypothetical attempt to soften amor, before his final submission: omnia uincit Amor: et nos cedamus amori (69). As this way of referring to midsummer heat does not come from Theocritus, it is perhaps drawn from Gallus, so one could imagine a more precise allusion than to the eclogues passage itself. 
Horos may be a charlatan, but his account of Apollo's prophecy to Propertius (4.1.135-46) ${ }^{84}$ contains a significant reminder of Cynthia's domination over Propertius, and modern readers ${ }^{85}$ have seen this poem as paired with $4.1 \mathrm{~A}$ in giving the programme for the whole book: apart from anything else they introduce a series of alternating pairs, aetiological followed by non-aetiological as far as Cynthia's unbalancing intrusion in 4.8, with the erotic theme stressed by Horos appearing in both sequences. So we get a book that merely toys with the aetiological material that was the obvious direction for the self-confessed Callimachean elegist heading away from the erotic. Propertius responds to the publication of the Aeneid by producing a book that shows epic inclusiveness of material from other genres: mimes $(4.1 \mathrm{~B}, 5)$, epigrams $(4.2,11)$, a letter $(4.3)$, hymns $(4.6,9)$, epicedia $(4.7,11)$, narratives reworked from epic $(4.7,8)$, a speech for the defence $(4.11)$. He drew attention to a critical shortcoming of that great epic in parodying its predictions of events past, its overburdening of fate. To the reworking of Evander and Aeneas's tour in 4.1, he added two other parodies of episodes from book 8: the battle of Actium from the shield (4.6), and Hercules' destruction of Cacus, condensed in 4.9 to allow room for a more elegiac scene as Hercules stands outside the door of the shrine of the Bona Dea and pleads with the priestess for admission.

The first of the aetiological poems proper describes not the origin of one of the great Augustan deities, but the slippery and demotic Etruscan Vertumnus, whose ability to shift shape from day to day is mimicked in the poem itself, as it changes direction line by line. ${ }^{86}$ It is no coincidence that this deity reappears in the Metamorphoses (14.642ff). Ovid thus marked a particular debt to his elegiac predecessor, who brought into Augustan poetry this image of unpredictable change, an effective alternative for the oppressive fatum which determines historical process in the Aeneid.

Poems 4.3 and 4.6 reprise themes from book 3, the former by giving greater vividness to the wife left behind by her husband sent on campaign to the East ${ }^{87}$; the latter by presenting Actium as not the end of warfare, but a force that corrupts even a Hymn to Apollo modelled on that of Callimachus. Propertius tries to move away from the military with a closural bella satis cecini (4.6.69), but the symposium that follows is spoilt by drunken poets singing of further wars. $\frac{88}{}$ Propertius himself is already moving towards silence.

\footnotetext{
${ }^{84}$ See C.E.Murgia, HSCPh 92 (1989), 268-70, for the case for attributing the lines to Apollo; this article also demonstrates the need to divide the poems $4.1 \mathrm{~A}$ and $4.1 \mathrm{~B}$ that have been amalgamated by the traditional numeration.

${ }^{85}$ E.g. J.P.Sullivan, Propertius: a critical introduction (Cambridge, 1976), 134-44; C.Macleod, 'Propertius 4.1', PLLS 1 (1976), 141-53 = Collected essays (Oxford, 1983), 20214.

${ }^{86}$ Vertumnus's opening words draw attention to the multiplicity of identities from whom the reader has already heard in the book (4.2.1 Qui mirare meas tot in uno corpore formas). Different voices follow in the poems to come: this variety is one of the most signal aspects of the book's imitation of the Aetia. But Vertumnus is the most vivid equivalent for the poet's own voice.

87 There is much insight in the brief note of M.B.Poliakoff, ICS 12 (1987), 93-6.

${ }^{88}$ In substance and form verses 79-82 seem to parody Horace, Epist. 1.1.8.56-7 sub duce, qui templis Parthorum signa refigit/ nunc et, siquid abest, Italis adiudicat armis.
} 
Perhaps the strangest poem in the corpus is $4.10 .^{89}$ Unlike the aetiological poems earlier in the book, there is no attempt to elegiacize the material. In 4.2 and 4.9 we find the deity/hero dressing in women's clothing; in 4.4 Tarpeia betrays the city for love; even in 4.6 a debt to Callimachus and Philitas is asserted. Here, not only is the winning of the spolia opima as heroically military a topic as one can imagine, but the treatment is comparatively

straightforward, and shockingly bloody (4.10.11-12, 37-8, 43-4):

hic spolia ex umeris ausus sperare Quirini

ipse dedit, sed non sanguine sicca suo....

di Latias iuuere manus: desecta Tolumni ceruix Romanos sanguine lauit equos. ...

illi uirgatas maculanti sanguine bracas ${ }^{90}$ torquis ab incisa decidit unca gula.

It is almost as if Propertius is writing a poem as untypical as possible. Harrison has argued that the emphasis on the three dedications is an indication of support for Augustus's refusal to grant the spolia opima to Crassus, who had killed Deldo, king of the Bastarnae, in single combat in 29 B.C. ${ }^{91}$ In this instance it seems to me that the reader is presented with a real choice: there is nothing here that disputes the Augustan version (but also no direct reference to it). Is this a sign that Propertius's opposition has ended, or rather that it has become more cautious? Another noteworthy feature is the length with which the three episodes are treated: 18 verses for Romulus, 16 for Cossus, 6 for Claudius (and this imbalance contrasts with the even four lines for introduction and conclusion). How different from the annalistic norm by which (in general) the treatment gets longer the closer to the author's own day! The elegist inverts Livy's pattern, and does not take the opportunity to dwell on Claudius Marcellus. One might almost wonder whether the fourth claim, that of Crassus, denied by Caesar in 29, has been a victim of the gradual shortening, the movement towards silence. The contraction suggests boredom with the topic, and we should not be surprised to find a reprise of the bella satis cecini with which he has signed off from the narrative of Actium at 4.6.69: after a poem that seems to show how alien to Propertius's voice 'Augustan' aetiology could be, he starts 4.11, his final publication, with a resounding Desine, 'Stop'. And that is just what he does.

The final poem is so heavily marked as closural that it seems clear the author did not intend to write more: it concentrates on the themes of death and burial, and has repeated allusion to motifs such as the closing of doors (2), the finality of death (2-8), satiety (we should read sat, not sic in 9), completeness (45-6, 71-2; causa perorata est, 99). ${ }^{92}$ Many details point to features of elegy: the attempt to open doors with prayers, the importance of lament and tears, the female voice, and her death. Even the opening desine is reinforced by the next syllable: the Greek equivalent pauve is evoked by Paulle. Politically, this poem might seem supportive of the regime: it gives us a matron who fulfils many Augustan ideals, a uniuira who has produced three children and earnt the ius trium liberorum (35, 61-2). However, in this respect she reads as a reproach for Livia, wife of the princeps, whose claim to such honours was based on power not reality. The phrase communia pignora, natos (73) is

${ }^{89}$ For a reading that pursues far further the ideas touched on here, see J.Ingleheart, 'Propertius 4.10 and the end of the Aeneid: Augustus, the spolia opima and the right to remain silent', G\&R 54 (2007), 61-81.

${ }^{90}$ So Waardenburgh; persuasively supported by Goold, HSCPh 71 (1966), 89: illi uirgatis (iurgatis $N W$ : nigratis $F$ ) iaculantis ab agmine (agmina $N$ ) bracis (pracis $F$ : brutis $L$ ) W.

${ }^{91}$ S.J.Harrison, 'Augustus, the poets and the spolia opima', CQ 39 (1989), 408-14.

${ }^{92}$ See also W.R.Johnson, in D.H.Roberts et al. (edd.), Classical closure (Princeton, 1997), 163-80. 
especially sharp: Augustus and Livia have no children in common. ${ }^{93}$ In her apology for her life she adduces Caesar himself as evidence for her respectability (4.11.57-60):

maternis laudor lacrimis urbisque querelis, defensa et gemitu Caesaris ossa mea.

ille sua nata dignam uixisse sororem increpat, et lacrimas uidimus ire deo.

This acknowledges Caesar's grief, but it also raises question about his divinity.

But the real political edge is more indirect. Cornelia is presented as speaking for herself (27) now for the first time, in death. She presents her public face, with her honour expressed through the distinction of her ancestry (29-32, 37-40, 51-4 ${ }^{94}$ ), of her family (55-60, 65-6), of her husband, and the fact that she has left children to keep on the family line. Family is the main channel for the transmission of power in Rome, and this has been increased by the need to find where it will go after Augustus. The role of the matrona is central. Cornelia here claims for herself the victories and magistracies of her menfolk; she even finds in an unbroken marriage a woman's triumph (71-2):

haec est feminei merces extrema triumphi,

laudat ubi emeritum libera fama torum.

Of her own life aside from childbirth we are told nothing positive: she is imitable (44) precisely because she has not provoked comment. Marriage, childbirth and death mark out her life (35-6):

iungor, Paulle, tuo sic discessura cubili

ut lapide hoc uni nupta fuisse legar.

Between the two torches is the distinction of many negatives (41-50):

me neque censurae legem mollisse neque ulla

labe mea nostros erubuisse focos.

non fuit exuuiis tantis Cornelia damnum:

quin et erat magnae pars imitanda domus.

nec mea mutata est aetas, sine crimine tota est:

uiximus insignes inter utramque facem.

mi natura dedit leges a sanguine ductas,

nec possis melior iudicis esse metu.

quamlibet austeras de me ferat urna tabellas, turpior assessu non erit ulla meo.

This sense that her life has been a cipher is summed up in 11-12:

quid mihi coniugium Paulli, quid currus auorum

profuit aut famae pignora tanta meae?

What has the service of family done for Cornelia? The question is sharpened by the contrast with 4.7, where another female ghost speaks. Cynthia is as vibrant in death as she was in life, bitchy towards her rival, affectionate or malicious towards her slaves, full of memories of her nocturnal trysts with the poet, and of his betrayal of her in death. For her a memorial column on the road to Tibur, and the epithet aurea, and hopes of skeletal intercourse yet to come, not the continuing self-effacement of a Cornelia, who scarcely wishes her husband to remember her. What different images of Roman womanhood! And which did Propertius favour? His middle-aged commentators may have fallen in love with Cornelia, the Queen of Elegies; little

${ }^{93}$ A point made by John Henderson in a paper to the Corpus Seminar, Oxford, 4th December 1991. My views were greatly affected by his reading of 4.11 .

${ }^{94}$ Here, admittedly, we see signs of an alternative, feminine, history. 
reason to think that the poet did. ${ }^{95}$ An epicedion for a minor member of the imperial household? Time to stop.

So here we have a poet who dramatizes his moment of silence; he realizes that writing elegy as he has conceived it requires him to deal with Augustus and his power, and this means speaking the language of the regime and thus providing succour that he wishes to deny it. The man who never writes a word may be more perfect in his defiance, but such uprightness is a private thing, unseen by public, unknown by posterity. To choose not to write after winning fame, that is a glorious thing. And so Propertius wins his place beside Gallus, the suicide, and Ovid, the exile.

\section{A short story}

A boy growing up in a well-off family in Umbria in the 40s B.C. was scarred by the many deaths caused by the Perusine War, and by the loss of an uncle in particular. He developed an understandable hatred of warfare and of the young commander of the forces that brought such destruction to his homeland. Horrifyingly, that individual built on the power and wealth he gained through his adoption by the assassinated dictator Julius Caesar and on his own reputation for ruthlessness, and 10 years later he was unquestionably the dominant figure in Rome, and with only one rival in the Empire, Antonius, previously his brother-in-law and colleague, but now living as consort of Cleopatra, queen of Egypt. Conflict ensued, and decisive battles took place in and off the coast of Greece, and then in Alexandria. Caesar's heir returned to Rome triumphant.

In the meantime the Umbrian lad had become a poet, delighting in the influence of Catullus and the other neoterics, with their disdain for political bigwigs and their delight in publishing to the world their loves and hates. He conceived a book of elegies in which he would explore a love affair, with a mistress he called Cynthia (in homage to the great Greek elegist Callimachus, who repeatedly used the epithet Cynthian for Apollo, god of poetry). In combination with his elevation of love and love-poetry as a way of life, he established his distance from the political world of magistracies and foreign travel by introducing into the text as a contrast to himself a young acquaintance, Tullus, whose uncle has been consul, and whose wealth is ostentatiously displayed. He also included as a coda to the book an epigram written early in his poetic development that commemorates with ingenious topicality the death of his uncle in the Perusine War, and then another epigram to explain the relevance of this piece to him, the poet.

The book was successful, read all over Rome, and there was thought that the poet might join the circle of Maecenas, Caesar's side-kick, and pillar of the regime. In his following books the elegist teased his readers with intimations that he might have been bought by the regime,

${ }^{95}$ Little, but not none. At 1.12.20 he announced Cynthia prima fuit, Cynthia finis erit. The first part is entirely accurate in reporting his opening; he could have finished with 4.7 (or 4.8) and ensured accuracy for the second half. By ending with Cornelia, he has left open to readers the possibility of taking Cornelia, the historical figure, as Cynthia, the fictional mistress. We would then have a moment of identity revealed like that Catullus gives us in poem 79 (Lesbius est pulcher), and the most amazing contrast between the public face of the grand materfamilias and the woman he knew in backstreets and life. 
but he maintained his distance: for every fleeting moment of flattery there are two of sarcasm and disdain. Though writing mainly about Cynthia and poetry, the poet did not ignore the reality of where power lay in Rome, but used his words to express his abhorrence for the policies and ideals of the regime. He stressed the bloodiness of warfare and the greed involved in Rome's expansionism. He exposed the incoherence between the emphasis given to family life and the military needs of empire, which sent young men abroad for long periods. He remained the Umbrian patriot, an Etruscan in Rome, and re-asserted this in his final book. This book moved away from the concentration on Cynthia and love, or at least it teased the reader once again by seeming to, and as well as the exploration of some aspects of the Roman past through aetiology, it showed the extraordinary range that elegy could achieve. It closed with two poems that suggested closeness at last to the regime: one that celebrated the greatest deeds in Roman arms, the winning of the spolia opima, and one that commemorated the passing of an ideal Roman matron, Cornelia, lamented by Caesar himself. The first words of the final poem were Desine, Paulle: in Latin and Greek the poet told himself that it was time to stop. He realised at the end that political writing, however sarcastic in phrasing, is in danger of bolstering the very regime it attacks. He ended his life in cunning silence. ${ }^{96}$

S.J. Heyworth Wadham College, Oxford

96 This paper is based on a talk I gave at the Institute in December 2003, on the invitation of Alessandro Schiesaro; I am very grateful to him for his encouragement, and to Sergio Casali, Sandro Barchiesi, Jennifer Ingleheart, an anonymous referee, and others, including a number of Wadham students, for their helpfully critical responses. 